\title{
ARTÍcULOS
}

\author{
[La evolución]
}

\section{LA EVOLUCIÓN BIOLÓGICA EN LA BIOFILOSOFÍA DE F. J. AYALA}

\author{
DIEGO CANO ESPINOSA \\ Doctor en Filosofía
}

\begin{abstract}
RESUMEN: El discurso biológico de Ayala se centra en estas tres cuestiones: 1) El hecho de la evolución. 2) Historia de la evolución. 3) Mecanismos del desarrollo y cambio evolutivos. El hecho determinante y cierto, según Ayala, es la evidencia de relaciones entre todos los organismos debidas a una común descendencia con modificaciones como lo han demostrado con abundancia la Paleontología, Anatomía comparada, Biogeografía, Embriología, Genética Molecular, Bioinformática y otras disciplinas biológicas que nos llevan a la afirmación de que el hecho de la evolución de los seres vivos tiene el mismo grado de certeza que poseen los hechos históricos y científicos ampliamente confirmados. Para Ayala, explicaciones acerca del origen del mundo, del hombre y de otras criaturas se encuentran en todas las culturas. Tras la publicación del Origen de las Especies de C. Darwin en 1859, se produce gran polémica en los medios científicos, culturales y religiosos, pero pasado un período de maduración, el darwinismo logra ser aceptado especialmente bajo las formas de Neo-darwinismo y Teoría Sintética. Otro asunto muy distinto son las diversas teorías y micro-teorías que se proponen para explicar los mecanismos de la evolución de los organismos vivos que presentan todavía profundas lagunas, deficiencias y controversias que han provocado la aparición de teorías alternativas. No obstante, el darwinismo moderno constituye un peldaño importante en la reconstrucción del sinuoso y complejo proceso evolutivo de la vida a través de millones de años acudiendo a una razonable explicación causal sin que esto atente contra ningún supuesto religioso.
\end{abstract}

PALABRAS CLAVE: evolución, cambio, adaptación, eficacia biológica, selección natural, acervo genético, variabilidad genética, especie, creacionismo, microevolución, macroevolución, reloj molecular, Genética Molecular, Ingeniería genética.

\section{The Biologic Evolution in Epistemology of F. J. Ayala}

ABSTRACT: Ayala's reasoning on evolution is based on this three questions: 1) The historical fact of evolution; 2) the evolution history and 3) the mechanisms of evolutionary developments and changes. The determinant and correct fact, it ist, the evidence of relation between lives organims due to the origin from a common ancestor with modifications as been demonstrated by a plentiful arguments supported by the Paleontology, Anatomy, Biogeografy, Molecular Genetic, Bioinformatic and other biologics disciplines. The concurrence of arguments lead to the conclusion: the fact of evolution has the same grade of certainty that historical and scientific facts speciously confirmed. According Ayala, in all cultures there different stories on explanation about origin of world, living organims and man. After the publication by C. Darwin of Origin of Species (1859), controversies appeared in cultural and religious melieus. Finally, the Darwinism was accepted in the form of Neo-Darwinism and Synthetic Theory. Other question is the study of the different theories wich explain the mechanisms of evolution; the presence of deep gaps and deficiencies in the evolutionary trees resulted in the appearance of alternative theories. However, the modern Darwinism constitutes one significant step in the reconstruction of the complex process of live development across millions of years, turning reasonable causal explanation without commiting any outrage againts religious believes.

KEY WORDS: evolution, change, adaptation, fitness, natural selection, genetic variability, genepool, species, creacionism, microevolution, macroevolution, molecular watch, Molecular Genetic, Genetic Engineering. 
«En Biología nada tiene sentido si no es a través del prisma de la evolución». Son palabras escritas por T. Dobzhansky en 1973 y que coronan el pensamiento biofilosófico de F. J. Ayala. Posiblemente Ayala, su discípulo predilecto, cautivado también por esta idea, escribe:

Hace ya más años de los que quiero recordar, decidí dedicar mi vida al estudio de la evolución biológica. Era la ambición ingenua de mi juventud alcanzar una comprensión profunda del mundo y de mí mismo. Las realidades más complejas, más interesantes y más bellas de este mundo son los seres vivientes. Así, pues, mi interés inicial por la Física se trocó en interés por la evolución, comenzando por la genética, la ciencia que explica la transmisión de las características de los seres vivos de generación en generación ${ }^{1}$.

Aunque la idea de evolución está referida siempre en este trabajo a los seres vivos, es posible encuadrar esta evolución particular en una evolución general cósmica ${ }^{2}$. El proceso de la evolución es un hecho contrastable. Como fenómeno cósmico ha sido descubierto por las diferentes ciencias, Cosmología física, Astronomía, Geología, Paleontología etc., aunque por su lentitud en millones de años comparado con nuestra escala de vida no sea directamente observable.

Es más frecuente utilizar el término evolución aplicado a los organismos vivos, y en este sentido, el hecho de la evolución de la vida puede ser constatado por cualquiera guiado del sentido común sin necesidad de ser especialista en la materia. Como dice I. Núñez de Castro:

Cuando observamos un organismo vivo a lo largo del tiempo, constatamos que todo viviente debe ser considerado como un proceso. El viviente no puede ser definido atemporalmente. El viviente lo definimos desde el tiempo y dependerá de la escala de tiempo que utilicemos la consideración del proceso. (...) La consideración del devenir de un organismo desde su comienzo hasta su fin nos definirá un tiempo ontogenético. Si consideramos poblaciones de individuos y los mecanismos hereditarios, tendremos el tiempo genético. En una escala cronológica que abarque centenares de generaciones se registrarán lentos procesos de cambio que desembocan en nuevas especies y tendremos el tiempo filogenético o tiempo evolutivo. Vivir es, pues, permanecer en un proceso continuo de cambio, vivir es evolucionar. (...) La evolución no es más que la visión humana en la escala temporal filogenética de esa continua emergencia de novedad que llamamos viviente ${ }^{3}$.

1 Ayala, F. J., La naturaleza inacabada, (Ensayos en torno a la evolución), Editorial Salvat, Barcelona, 1994, Prólogo.

2 Simpson, G. G., This view of Life, Editorial Harcourt, Brace and Worl, New York, 1961, p. 7. A este propósito dice Simpson: la evolución orgánica es uno de los hechos fundamentales y característicos de la realidad objetiva. En cierto sentido, es el hecho más básico de la realidad, puesto que es el proceso por el que se originan las complejidades mayores del universo y que culmina la organización sistemática. Puesto que es el proceso por el que nosotros venimos a existir, es absolutamente esencial para la comprensión de nuestra posición en la realidad objetiva y nuestra relación con ella.

3 Núñez de CASTRo, I., «La evolución de la vida», "Comunicació: Revista del Centro d'Estudis Teológics de Mallorca», nº 93, 1999, p. 85. 
X. Zubiri nos dice, que lo inorgánico permanece a pesar del cambio, por diferencia el ser orgánico cambia para permanecer ${ }^{4}$. Como recuerda Ayala ${ }^{5}$ : La diversidad de especies vivientes conocidas es asombrosa. Existen descritas y nominadas más de dos millones de plantas y animales.

Tres son las cuestiones a estudiar, según el profesor Ayala ${ }^{6}$ :

- El hecho en sí de la evolución.

- Historia de la evolución.

- Mecanismos del desarrollo y cambio evolutivos.

La primera cuestión es la básica, puesto que si los organismos no evolucionan, las teorías sobre la evolución no tendrían sentido. La evidencia de este hecho se va incrementando con la aportación de todas las disciplinas biológicas. Que la evolución sea un hecho hoy, dice Ayala, significa, que como conclusión científica, goza de una certeza comparable a la de otros hechos científicos.

\section{Concepto de evolución según F. J. Ayala}

Puede hablarse de evolución en sentido teológico, metafísico, histórico, biológico etc., sin embargo, no deben separarse excesivamente estos significados porque llevaría a olvidar los elementos comunes que existen en el concepto de evolución. Ayala, como es obvio, lo utiliza en sentido netamente biológico. Es oportuno recordar con E. Gilson ${ }^{7}$ que Darwin no usa el término evolución hasta la sexta edición de El Origen de las Especies.

Para Ayala ${ }^{8}$, el concepto de evolución añade a nuestra concepción del universo la dimensión temporal. La realidad sólo se puede comprender como proceso histórico. Siguiendo a Teilhard de Chardin, utiliza una frase de éste: El tiempo y el espacio están orgánicamente unidos como entretejiendo la realidad del universo y es el modo cómo entendemos hoy las cosas. Sin embargo, aunque no facilita Ayala una definición taxativa propia de evolución, sí nos remite a una definición dada por G. L. Stebbins en 1969: la evolución es la emergencia gradual y alteración adaptativa de sistemas de orden que no pueden ser destruidos de manera reversible ${ }^{10}$.

4 Zubiri, X., Espacio, Tiempo, Materia, Alianza Editorial S.A. Madrid, 1996, p. 666. Imposible encontrar un ser vivo estático, sería un cadáver, y es que la esencia de la vida es el movimiento, movimiento ab intriseco, cambio o evolución no siempre para mejorar sino irreversible para permanecer, sobrevivir.

5 Ayala, F. J., «The evolution of life: An Overview», Evolutionary and Molecular Biology, o.c. p. 21.

6 Ayala, F. J., La Teoría de la Evolución, (De Darwin a los últimos avances de la Genética), Ediciones Temas de Hoy, Madrid, 1994, pp. 17-18.

7 Gilson, E., De Aristóteles a Darwin (y vuelta), o.c. pp. 115-142.

8 Ayala, F. J., «Evolución, Tiempo y Filosofía», «Arbor», o.c. p. 188.

9 Teilhard de Chardin, P., Le phénoméne Humain, Editions du Seuil, 1955, p. 241.

10 Stebbins, G. L., The basis of Progressive Evolution, University of North California Press, 1969, p. 119. 
No es fácil dar una definición completa de evolución, como apunta más tarde Stebbins ${ }^{11}$ : Según Stebbins, una definición de evolución correcta debe incluir todos sus aspectos y que distinga bien la evolución del mero cambio.

\section{El CONCEPTO DE EVOLUCIÓN EN LA HISTORIA DEL PENSAMIENTO}

Para el profesor Ayala ${ }^{12}$, explicaciones acerca del origen del mundo, del hombre y de otras criaturas se encuentran en todas las culturas humanas.

En la Grecia clásica encontramos mitos sobre la creación, algunos con re-

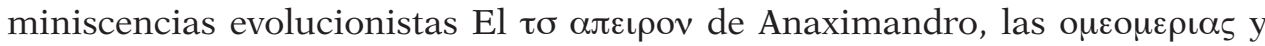

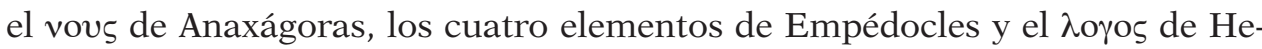
ráclito son como la razón-ciega que conduce a la materia, origen de todos los seres, a su determinación y se asemeja mucho a la razón-alma de los vitalistas, al l'élan vital de Bergson y a la selección natural de C. Darwin. Sin embargo, son objeto de discusión las ideas evolutivas de Aristóteles. La interpretación que hace Ayala al respecto y en la que siempre sigue a J. H. Randall, es la siguiente:

Aristóteles era un observador cuidadoso de la naturaleza, pero para él también todo cambio es en sí mismo negación del ser. La naturaleza consta de acto y potencia; el acto es verdadera realidad, la potencia es carencia o negación de realidad. Las esencias de las cosas son, en cualquier caso, inmutables. Toda la realidad está moldeada según las esencias eternas. Si las cosas materiales cambian es porque la materia es potencia. El cambio, el movimiento y el tiempo son «accidentes» de la realidad que no modifican las esencias de las cosas ${ }^{13}$.

Y J. H. Randall escribe:

Para Aristóteles la evolución cósmica no existe; para él nunca ocurre nada nuevo o diferente. Se ha dicho con razón, que para Aristóteles la naturaleza es como un ejército siempre marcando el paso, pero sin ir hacia ningún sitio ${ }^{14}$.

J. H. Randall afirma con rotundidad que Aristóteles no admite la evolución, a lo que se opone Alfredo Marcos ${ }^{15}$. Recuerda éste, que toda la filosofía del estagirita es un intento de salvar, a la par, la realidad del cambio y la inteligibilidad

11 Dobzhansky, Ayala, Stebbins, Valentine, Evolución, o.c. pp. 9-10.

12 Ayala, F. J., «The evolution of life: An Overview», Evolutionary and Molecular Biology, o.c. p 22-23 y La Teoría de la Evolución, o.c. pp. 25-44.

13 Ayala, F. J., «Evolución, Tiempo y Filosofía», «Arbor», 1969, n. 74, p. 191.

14 Randall, J. H., Aristotle, Columbia University Payperbacs, 1963, p. 138, citado por Ayala.

15 En efecto, Aristóteles lejos de negar el movimiento, cambio, como su antecesor Parménides, no sólo lo admite y le preocupa como realidad, sino que es el primero en explicarlo utilizando los conceptos de acto y potencia. No se olvide, que la forma aristotélica es

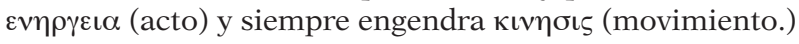


de la naturaleza. Marcos ${ }^{16}$ sugiere que no existe una incompatibilidad radical e incluso que la teoría aristotélica admitiría una extensión evolutiva.

Con más proximidad al concepto actual de evolución, recuerda Ayala ${ }^{17}$, que algunos Padres de la Iglesia primitiva como S. Gregorio Nacianceno (330-390) y S. Agustín de Hipona (354-430) sostienen que no todas las especies de plantas y animales fueron creados desde el principio por Dios, sino que algunos se han desarrollado a partir de especies o semillas creadas por Él, (rationes seminales.)

En la Edad Media, S. Alberto Magno (1200-1280) y su discípulo S. Tomás de Aquino estudian la posibilidad de la generación espontánea, como se creía en aquella época. S. Tomás enumera las razones filosóficas y teológicas en pro y en contra y, por tanto, ni afirma ni niega porque es asunto a resolver por los científicos ${ }^{18}$.

Una figura española relevante por sus ideas sobre la evolución biológica es José de Acosta (1540-1600), jesuita, misionero, naturalista y antropólogo en Hispano América. Según Leandro Sequeiros ${ }^{19}$, Acosta ensaya tres soluciones en las que intervienen argumentos naturalistas y filosóficos. Esquemáticamente estas respuestas serían: $1^{\text {a }}$ ) «Allá los produjo el Creador»: solución teológica (Creacionista.) 2 $2^{\mathrm{a}}$ «Se conservaron en el Arca de Noé... y se fueron a distintas regiones»: solución teológico-geográfica. (Diluvista) $3^{\mathrm{a}}$ ) «Reducirlos a los de Europa»: solución transformista. (Evolucionista.)

En su valiosa aportación a las ciencias naturales, en expresión de Sequeiros, Acosta manifiesta su epistemología de talante moderno.

Destaca el gran naturalista francés Jean-Baptiste de Monet, caballero de Lamarck (1744-1829). Lamarck defiende que se dan modificaciones en los organismos al adaptarse a su ambiente por cambio de hábitos. El uso de un miembro u órgano lo refuerza y el desuso lo conduce a su eliminación gradual.

A juicio de Ayala, el valor fundamental de la obra de Charles Darwin está en haber producido la Revolución darwiniana que completa la revolución copernicana iniciada en los siglos XVI y XVII y ampliadas por Galileo Galilei e I. Newton. Para Ayala, con la revolución copernicana el funcionamiento del universo deja de ser atribuido a la inefable voluntad del Creador y pasa al dominio de la ciencia, que es una actividad intelectual que trata de explicar los fenómenos del universo por medio de causas naturales ${ }^{20}$. La revolución copernicana intenta sustituir la explicación teológica de los fenómenos naturales por la explicación científica. La revolución darwiniana hace lo mismo pero aplicada a los seres vivos. Pero

16 MARcos, A., o.c. p. 266.

17 Ayala, F. J., La Teoría de la Evolución, o.c. pp. 26-30.

18 Ayala hace un recorrido histórico sobre los personajes que han defendido de un modo u otro la evolución de los seres orgánicos en La teoría de la Evolución, o.c. pp. 26-30. No es necesaria su repetición en este trabajo por ser suficientemente conocida la historia de los acontecimientos evolutivos.

19 Sequeiros, L., «José de Acosta (1540-1600) y sus ideas sobre la evolución biológica, cuatro siglos después», La Nueva Alianza entre Ciencias y Filosofía, ed. Blanch, A., ASINJA, Universidad Pontificia de Comillas, Madrid, septiembre de 2000.

20 Ayala, F. J., La Teoría de la evolución, o.c. pp. 30-31. 
más importante que demostrar el hecho de la evolución es dar una explicación causal de este hecho con su teoría de la selección natural. Como dice F. J. Aya$\mathrm{la}^{21}$, la dificultad más seria que padecía el darwinismo era la carencia de una teoría que explicara la persistencia de la herencia de generación en generación, y las variaciones sobre las que actúa la selección natural como el eslabón para completar la cadena argumental de C. Darwin.

En 1866 publica el monje agustino Gregorio Mendel en Proceeding de la Sociedad de Historia Natural de Brünn los resultados de sus experimentos con Pisum sativum y Mirabilis jalapa en el jardín de su monasterio de dicha ciudad ${ }^{22}$.

Entre los defensores del darwinismo se distingue el biólogo alemán August Weismann (1834-1914) quien publica su teoría sobre el germoplasma ${ }^{23}$. Redescubierta la teoría mendeliana de la herencia en 1900 por el holandés Hugo de Vries y el alemán Carl Correns casi simultáneamente, ponen el énfasis, como dice Ayala ${ }^{24}$, en el papel de la herencia en la evolución. De Vries propone una nueva teoría de la evolución conocida por mutacionismo y que elimina el concepto de selección natural como el proceso principal de la evolución ${ }^{25}$.

Esta teoría de la mutación rápida y repentina fue rechazada por muchos naturalistas y especialmente por los llamados biometristas liderados por el matemático inglés Karl Pearson. Éstos defendían que la selección natural es la causa principal de la evolución que se realiza a través de los efectos acumulativos de variaciones pequeñas y continuadas. Estas variaciones se llaman métricas o cuantitativas porque se pueden medir y no son cualitativas porque no sirven para distinguir las especies.

Según Ayala $^{26}$, la cuestión era si las especies aparecen de forma repentina por mutaciones importantes (cualitativas), o de manera gradual por acumulación de variaciones pequeñas (cuantitativas.) Para la resolución de la controversia,

21 Ayala, F. J., La Teoría de la evolución, o.c. pp. 36-37.

22 En su teoría, expone G. Mendel, los principios fundamentales de la herencia biológica, con vigor todavía en la actualidad. Esta teoría dice que la herencia biológica se produce a través de pares de factores heredados (genes) cada uno de un progenitor, y que no se mezclan sino se disgregan en los gametos o células sexuales. Esta explicación permaneció desconocida hasta 1900, cuando fue descubierta de nuevo por científicos europeos.

23 En ella distingue Weismann en todo organismo dos componentes: el somatoplasma que comprende las principales partes del cuerpo y sus órganos, y el germoplasma que contiene las células que darán origen a los gametos y a la herencia. Esta separación de soma y germen, según Weismann, hace imposible la transmisión de los caracteres adquiridos y deja paso abierto a la selección natural como único medio para explicar las adaptaciones biológicas. Las ideas de Weismann son conocidas desde 1896 como el neodarwinismo.

24 Ayala, F. J., La Teoría de la evolución, o.c. pp. 38-39.

25 Para de Vries y otros, hay dos tipos de variación en los organismos: la variación ordinaria que se da entre los individuos de una especie y no tiene trascendencia hereditaria fuera de la especie, como el color de los ojos, de las flores o el tamaño y la mutación genética que se produce por mutaciones espontáneas de los genes y que dan lugar a que puedan originarse nuevas especies. Una nueva especie se origina de repente de otra anterior, de forma imprevisible y sin transición.

26 Ayala, F. J., La Teoría de la evolución, o.c. pp. 39-41. 
el primer paso fue descubrir que la herencia de las variaciones cuantitativas obedece a las leyes mendelianas y están determinadas por varios genes, cada uno con efecto muy pequeño. Varios teóricos de la Genética demostraron matemáticamente que la selección natural actuaba de modo acumulativo sobre variaciones pequeñas que producían cambios importantes en la forma y función $^{27}$. En 1937 el genetista ruso Theodosius Dobzhansky, de nacionalidad estadounidense, publicó su obra La Genética y el Origen de las especies con la que contribuyó de forma intensiva a la formulación de la llamada teoría sintética o teoría moderna de la evolución, en la que se integran la selección natural de C. Darwin y la genética mendeliana ${ }^{28}$. En 1953 la Biología molecular recibe un gran impulso con el descubrimiento de la estructura del DNA por J. Watson y F. Crick. En 1968 el genético japonés Motoo Kimura presenta su teoría neutral de la evolución a escala molecular, llamada también teoría no darwinista o teoría de la trayectoria neutral, según la cual, los cambios en las secuencias del DNA y proteínas son adaptativamente neutrales. En los últimos años se ha descubierto que las técnicas de clonación y secuenciación del DNA ofrecen un medio poderoso para conocer la evolución molecular ayudadas de la Bioinformática. Por último, la Geología y Geofísica, la Ecología, la Etología y la Sociobiología han contribuido también de forma notable al conocimiento del proceso evolutivo.

No podemos terminar esta reseña histórica sin hacer algunas referencias, las más importantes, al impacto de la teoría de la evolución en los medios culturales y especialmente religiosos. El profesor Ayala escribe:

La publicación del Origen de las Especies en 1859 tuvo gran impacto en la sociedad de su tiempo, inmediatamente en Inglaterra, pero enseguida también en el resto de Europa y en América. El libro se convirtió en tópico de salón sujeto a vehementes ataques e incluso al ridículo. Científicos, políticos, clérigos y personas notables de todo tipo discutían el libro, defendiendo o negando las ideas de Darwin. Los ataques mencionaban frecuentemente el origen de los humanos a "partir del mono» como proposición ofensiva e inaceptable. Pero subyacente a ésta y a otras críticas residía una objeción fundamental: la que se opone al diseño en el universo, particularmente del diseño de los seres vivos por medio de causas naturales. Dios, el gran diseñador de la concepción de Aquino y Paley, queda remontado, en el mejor de los casos, al papel de Creador del mundo original y de sus leyes inmanentes en vez de ser responsable de la configuración y la operación de los organismos y del resto del universo ${ }^{29}$.

En este contexto, es fácil comprender las controversias de orden religioso surgidas especialmente entre los teólogos de la Cristiandad, debidas a la falsa

27 Entre estos genéticos destacaron: R. A. Fisher, J. B. Haldane y S. Wright.

28 Entre los autores que colaboran con T. Dobzhansky a perfeccionar y extender la teoría sintética destacan en Estados Unidos, además de F. J. Ayala, el zoólogo E. Mayr, G. Simpson paleontólogo y el botánico G. L. Stebbins; el zoólogo J. Huxley en Inglaterra y B. Rench en Alemania.

29 Ayala, F. J., La Teoría de la evolución, o.c. p. 34. 
interpretación literal que se hacía en aquel tiempo de la lectura de la Biblia, sobre todo, de los primeros pasajes del libro del Génesis ${ }^{30}$.

Ayala ${ }^{31}$ centra su atención en dos teólogos. El teólogo inglés Willian Paley (1743-1805) defendía en su Natural Theology (1802) que no se puede concebir la organización compleja y precisa del ojo humano surgida como resultado del azar. Otro teólogo protestante americano Charles Hodge (1874) afirmaba que la teoría de C. Darwin constituía la más completamente naturalística que puede imaginarse, aún más atea que la de su antecesor Lamarck. C. Hodge defendía que el diseño del ojo humano manifiesta que ha sido planeado por el Creador.

Otros teólogos afirman que no hay incompatibilidad entre la teoría de la evolución, explicación causal, y la creación divina. La cuestión se resuelve aceptando que Dios opera a través de las causas segundas o intermedias, de las que ya hablaban los escolásticos. La ciencia puede explicar por causas inmediatas los fenómenos naturales sin negar, por ello, ni la existencia ni la creación de Dios. Como dice Ayala:

La evolución también puede ser considerada como un proceso natural, a través del cual, Dios trae las especies vivientes a la existencia de acuerdo con su plan ${ }^{32}$.

El eminente teólogo A. H. Strong, presidente del Seminario Teológico de Roschester en New York, en su libro Systematic theology (1885), citado por el profesor Ayala, escribe:

Aceptamos el principio de la evolución pero lo vemos sólo como el método usado por la Inteligencia Divina. Aceptar que los humanos tienen antepasados animales no es incompatible con su condición excepcional como criaturas hechas a imagen y semejanza de Dios. (...) El hombre no es una bestia, aun cuando la bestia haya contribuido de alguna manera a su creación ${ }^{33}$.

No obstante, en la década de los años 1920, continúa Ayala, los fundamentalistas creacionistas estadounidenses, defensores de la Ciencia de la Creación, consiguieron que cuatro estados: Arkansas, Mississipi, Oklahoma y Tennesee,

30 Ya muchos siglos antes, S. Tomás de Aquino demostró no ser incompatibles la fe y la razón. Ambas parten de puntos de referencia distintos y si sus planteamientos son correctos, no deben, ni hay motivo alguno para ello, estorbarse la una a la otra. Es más, pueden ayudarse mutuamente en la adquisición de conceptos más amplios, asunto este que se resuelve satisfactoriamente en nuestros días. Advirtamos el uso corriente que se hace del antropomorfismo cuando hablamos de Dios al no tener otro punto de referencia mejor que el hombre imagen y semejanza de Dios, según la Biblia. Ésta, desde sus primeras páginas, presenta a Dios en forma antropomórfica como si fuese un artesano que moldea el mundo en seis días y descansa el séptimo a semejanza del alfarero hebreo, metáfora propia del lenguaje mítico y entendida como tal por el pueblo creyente.

31 Ayala, F. J., «The evolution of Life: An overview», Evolutionary and MolecularBiology, o.c. pp. 28-9. También en Ayala, F. J., Origen y Evolución del hombre, Editorial Alianza Universidad, Madrid, 1995, p. 12.

32 Ayala, F. J., La teoría de la Evolución, o.c. p. 22.

33 Ayala, F. J., Ibidem, p. 22. 
prohibieran la enseñanza de la teoría de la evolución en las escuelas públicas. En 1968, La Corte Suprema de los Estados Unidos declaró esta ley como noconstitucional.

Nos recuerda Ayala ${ }^{34}$ que ya en el siglo xx la teoría de la evolución biológica es aceptada por los escritores cristianos. En 1950, el Papa Pío XII en su encíclica Humani generis reconoce que la evolución biológica es compatible con la fe cristiana, aunque para la creación del alma humana es necesaria la intervención de Dios. Finalmente, es el Papa Juan Pablo II en el discurso dirigido en 1981 a la Academia Pontificia de las Ciencias quien dijo textualmente:

La Biblia nos habla del origen del universo y sus componentes, no con el propósito de enunciar un tratado científico, sino en orden a establecer las relaciones apropiadas del hombre con Dios y con el universo (...) Es un error tomar la Biblia como un tratado introductorio de astronomía, geología y biología ${ }^{35}$.

En el discurso de 1996, a la misma Academia Pontificia de las Ciencias dijo: «La teoría de la evolución es más que una mera hipótesis»"

Todas estas aportaciones indican que gradualmente la evolución por selección natural ha sido bien recibida por la mayoría religiosa cristiana ${ }^{37}$.

Hoy podemos decir con certeza que no existe incompatibilidad alguna entre fe y ciencia, evolución y religión; ambas usan lenguajes propios, diferentes y, por tanto, incommensurables, lo cual no significa negar las buenas relaciones que deben reinar entre ellas puesto que las dos benefician al ser humano mientras se mantienen en su propio ámbito y cordura, respetando su dignidad.

\section{El hecho de la evolución. Comprobaciones}

Según Ayala:

La obra de C.Darwin tuvo una influencia de la que carecieron las teorías evolutivas anteriores porque obtuvo evidencia abundante de que la evolución biológica ha ocurrido de hecho ${ }^{38}$.

En realidad, lo que C. Darwin no pretendía al descender cada vez del Beagle en su periplo, era acumular datos recogiendo materiales orgánicos que examinaba minuciosamente para demostrar el hecho de la evolución biológica ${ }^{39}$.

34 Ayala, F. J., Ibidem, p. 22.

35 Ayala, F. J., «The evolution of Life: An Overview», Evolutionary and Molecular Biology, o.c. $\mathrm{p} 29$.

36 Ayala, F. J., Ibidem, p. 29. Para más detalle puede consultarse también el trabajo del autor «Darwin and the Bible», "History and Philosophy of Life Science», 1998, n 10, pp. 137-144.

37 Hay todavía regiones musulmanas donde el fundamentalismo religioso impide la enseñanza de la teoría de la evolución. Tal vez se debe a la ancestral confusión entre explicación arreligiosa y antirreligiosa, ésta como negación de Dios.

38 Ayala, F. J., «Evolución, Tiempo y Filosofía», «Arbor», o.c. p. 189.

39 CAstrodeza, C. Teoría histórica de la selección natural, Editorial Alambra, Madrid, 1988. Según este autor, Darwin no fue de viaje en el Beagle para recoger muestras y probar la 
Así parece deducirse del párrafo inicial de El Origen de las Especies ${ }^{40}$. Para el Dr. Ayala $^{41}$, desde el regreso del Beagle el 2 de octubre hasta la publicación de El Origen de las Especies y hasta el fin de su vida, Darwin buscó pruebas empíricas que confirmasen el origen evolutivo de los organismos y su teoría de la selección natural. El hecho determinante y cierto es, según Ayala $^{42}$, la evidencia de relaciones entre todos los organismos debidas a una común descendencia con modificaciones, como lo han demostrado las diferentes disciplinas biológicas.

\subsection{Pruebas paleontológicas del hecho de la evolución}

A pesar de las lagunas del registro fósil, que aún permanecen en la actualidad, muchas han sido cubiertas por la investigación de los paleontólogos desde C. Darwin. Cientos de miles de organismos fósiles encontrados en buen estado en rocas estratificadas representan una sucesión de formas a través del tiempo y ponen de manifiesto muchas transiciones de carácter evolutivo. Mayor evidencia presentan organismos más complejos como los eucariotas que fueron descubiertos fósiles en pedernal con unos 1.500 millones de años. Formas más desarrolladas como algas, hongos, grandes plantas y animales se han encontrado en estratos geológicos más recientes. El orden aproximado de aparición de formas complejas, según Ayala, puede ser éste:

\begin{tabular}{|lc|}
\hline Formas de vida & Millones de años \\
\hline Células procariotas & 3.500 \\
\hline Células eucariotas & 1.400 \\
\hline Primeros animales multicelulares & 670 \\
\hline Animales con caparazón & 540 \\
\hline Vertebrados (peces) & 490 \\
\hline Anfibios & 350 \\
\hline Reptiles & 310 \\
\hline Mamíferos & 200 \\
\hline Primates no humanos & 60 \\
\hline Primeros monos & 25 \\
\hline Austrolopitécidos & 5 \\
\hline Homo sapiens (Hombre moderno) & 150.000 \\
\hline
\end{tabular}

evolución. Su viaje no tenía ese objetivo. Durante su estancia en las islas Galápagos, Darwin seguía siendo un creacionista. Su adopción del transformismo fue posterior a su recogida de datos. Hasta 1838 no llega a formular el principio de la selección natural.

40 Darwin, C. El Origen de las Especies, Ediciones Akal, Madrid, 1994, traducción de Enrique Godinez.

41 Ayala, F. J., Evolución, Dobzhansky, Ayala, Stebbins, Valentine, Ediciones Omega S:A. Barcelona, 1993, p. 482.

42 Ayala, F. J., «The Evolution of Life: An Overview», Evolutionary and Molecular Biology, o.c. p. 29. 
La dificultad radica en señalar categóricamente cuándo y cómo ocurre la transición ${ }^{43}$. Todos los fósiles pueden ser considerados formas intermedias en algún sentido. Esta predicción está confirmada por la evidencia acumulada hasta aquíi ${ }^{44}$.

Algunos creacionistas, confirma Ayala ${ }^{45}$, han propuesto que todo el registro fósil con su ordenada secuencia es el producto de un singular diluvio universal que duró más o menos un año, primero cubrió las más altas montañas y después toda la tierra. Esta hipótesis de un diluvio universal cubriendo montañas no tiene apoyo científico ${ }^{46}$.

\subsection{Pruebas anatómicas del hecho de la evolución}

Confirma Ayala ${ }^{47}$ que las deducciones de la Paleontología acerca de un ancestro común para todos los organismos se han visto confirmadas por los argumentos de la Anatomía Comparada. Los esqueletos de un hombre, un perro, un pájaro y una ballena son asombrosamente similares a pesar de las diferentes formas de vida de estos animales y de la diversidad de sus ambientes. Esta semejanza permite comprender que la estructura básica de los miembros ya existía en los antepasados y ha sido modificada sólo lo necesario para cumplir funciones diversas junto con las relaciones de parentesco entre especies descendientes de un mismo antepasado. Las especies con un ancestro común reciente son anatómicamente más semejantes entre sí que las que tienen antepasados comunes más lejanos. A estas semejanzas estructurales llaman los científicos homologías con las que se explican muy bien, no sólo el hecho de la evolución sino también la filogenia o historia evolutiva de los organismos.

\subsection{Pruebas biogeográficas del hecho de la evolución}

Nos recuerda Ayala que la diversidad de la vida es espléndida; que aproximadamente viven 250.000 especies de plantas, 100.000 de hongos y 1.500 de

43 Son interesantes las especulaciones de L. Margulis y Raff and Mahler sobre la evolución de los procariotas a eucariotas. L. Margulis propone la hipótesis de la simbiogénesis bacteriana en Origin of Eukaryotic cells, Yale University Press, 1970. RafF, R. A. y MaHLeR , H. R., defienden la hipótesis de la invaginación de la membrana celular en «Symbiotic origin of mitokondria», «Science», 177, pp. 575-582, 1972. Puede verse también J. W. Valentine en Evolución, o.c. pp. 380-386.

44 Sobre el origen de los organismos pluricelulares y metazoos, puede consultarse Evolución, o.c. pp. 391-393 y 395-435.

45 Ayala, F. J., «The evolution of Life: An Overview», Evolutionary and Molecular Biology, o.c. p. 30. Sobre el Creacionismo puede consultarse la obra de Sober, E., Filosofía de la Biología, Alianza Editorial, 1996, pp. 59-103.

46 Las técnicas radiactivas, han prestado gran ayuda a la Paleontología para datar las épocas geológicas antiguas y así identificar las edades de los fósiles.

47 Ayala, F. J., «Evolution of Life: An Overview», Evolutionary and Molecular Biology, o.c. p. 31 . 
animales y de microorganismos, cada una ocupando su propio nicho ecológico. C. Darwin observó que en las islas Galápagos existían especies de pinzones diferentes de una a otra isla, y ausentes en el continente suramericano. La razón biológica de estas diferencias es, que al estar estas islas tan extremadamente alejadas de continentes y otros archipiélagos, muy pocos colonizadores pudieron llegar a estos lugares tan aislados. Las especies que llegaron encontraron muchos nichos ecológicos o ambientes desocupados sin especies competidoras o depredadoras, las cuales limitaran su multiplicación. Ante esta situación, las especies se diversificaron con rapidez dando lugar al proceso que se conoce como radiación adaptativa. Cómo pudieron llegar los primeros colonizadores a estos parajes tan lejanos lo resuelve hipotéticamente el mismo C. Darwin con sencillos experimentos realizados con otras especies, tema al que dedica los capítulos 12 y 13 de El Origen de las Especies ${ }^{48}$.

La explicación de todos los caprichos biogeográficos no está en que se trata de ambientes distintos más favorables a unas especies que a otras, dice Ayala ${ }^{49}$ en coordinación con C. Darwin. No hay razón para creer que los animales de Sudamérica no estén bien dotados para vivir en África y viceversa o que las islas Hawai y Galápagos u otras sean menos hospitalarias para especies ausentes. Como dice el Dr. Ayala:

La ausencia de muchas especies en un ambiente hospitalario en el que prosperan una variedad extraordinaria de otras especies, argüía C. Darwin, puede ser comprendida desde la teoría de la evolución que explica que las especies existen y evolucionan sólo en aquellos continentes o islas que fueron colonizadas por sus ancestros ${ }^{50}$.

\subsection{Pruebas embriológicas del hecho de la evolución}

Otra de las pruebas que aportan evidencia sobre un origen común de los seres vivos es la de la Embriología. Ayala ${ }^{51}$ refiere que C. Darwin y sus seguidores señalaron que todos los vertebrados se desarrollan de manera bastante similar durante las etapas tempranas, y que se van diferenciando cada vez más a medida que el desarrollo embrionario avanza hasta el estado adulto. La única explicación científica de esta similitud en las primeras fases del embrión entre organismos tan dispares como el hombre y la lagartija, según Ayala ${ }^{52}$, es que comparten patrones fijos de desarrollo heredados de un mismo ancestro y después son modificados según la dirección en la que evoluciona cada uno de los linajes. Es el propio C. Darwin el que recapitula todas estas pruebas a favor de la evolución de los organismos con estas palabras:

48 Darwin, C. El Origen de las Especies, Ediciones, o.c. 416-475.

49 Ayala, F. J., La Teoría de la Evolución, o.c. p. 58.

50 Ayala, F. J., Ibidem.

51 Ayala, F. J., La Teoría de la evolución, o.c. p. 55.

52 Ayala, F. J., Ibidem. 
Finalmente proclaman, a mi parecer, las diversas clases de hechos considerados en este capítulo, que las especies, géneros y familias innumerables que pueblan este mundo, descienden todos, cada uno dentro de su propia clase o grupo, de padres comunes, y han sido todos modificados en el transcurso de la descendencia, que yo sin vacilar adoptaría esta teoría, aun cuando no estuviera apoyada por otros hechos y argumentos ${ }^{53}$.

\subsection{Pruebas moleculares del hecho de la evolución}

Con una nueva disciplina conocemos el proceso evolutivo en su nivel molecular, y como afirma Ayala:

La Biología Molecular, la más reciente de las disciplinas biológicas, aporta la más detallada y convincente evidencia a favor de la evolución biológica ${ }^{54}$.

La importancia de este método radica en su precisión y finura y en que la evolución molecular ha mostrado con gran poder de convicción que todos los seres vivos, desde las bacterias al hombre, están relacionados por descendencia de antepasados comunes. Esta íntima relación escrita en los componentes moleculares de los organismos, está cimentada en el DNA, cuya organización y estructura a partir de cuatro nucleótidos es similar en bacterias, plantas, animales y seres humanos que, a su vez, sintetizan de modo semejante todas las proteínas a partir de los mismos veinte aminoácidos. La clave o código genético que regula y traduce la información es esencialmente la misma, así como los patrones metabólicos para producir energía y elaborar los componentes celulares, también son los mismos. Según Ayala ${ }^{55}$, esta conformidad en las estructuras moleculares que se extiende a todos los organismos, revela la existencia de ancestros comunes para todos los organismos y la continuidad genética entre éstos.

Para explicitar las deducciones de la Biología molecular acude Ayala a un símil muy significativo:

Si se encuentra que ciertas combinaciones de letras — planeta, árbol, mujer - son utilizadas con idéntico sentido en varios libros diferentes, uno puede estar seguro de que los lenguajes utilizados en dichos libros tienen un origen común. (...) Supongamos que dos libros son comparados, (...) los dos libros son idénticos página por página y palabra por palabra, excepto que ocasionalmente una palabra, digamos, una de cada cien es diferente. La conclusión obvia es que estos dos libros no han sido escritos de forma independiente; o uno de los libros ha sido copiado del otro, o ambos lo han sido del mismo libro original ${ }^{56}$.

53 Darwin, C., El Origen de las Especies, o.c. p. 528.

54 Ayala, F. J., La Teoría de la Evolución, o.c. p. 58.

55 Ayala, F. J., La Teoría de la evolución, o.c. p. 59.

56 Ayala, F. J., La Teoría de la evolución, o.c. p. 60. 
La Biología molecular permite comparar el DNA y las proteínas, como dice el Dr. Ayala ${ }^{57}$, entre organismos tan distintos como una ameba y un ser humano, cosa que es imposible utilizando sólo su anatomía o embriología. La Biología molecular comprueba el hecho evolutivo haciendo uso del genotipo que porta la información de las características genéticas de la herencia y no del fenotipo cuyos cambios evolutivos no se heredan porque no tienen un fundamento genético.

\section{VARIABILIDAD GENÉTICA}

El verdadero punto de partida de la evolución biológica es lo que llaman los biólogos variabilidad genética; sin ésta se haría imposible el fenómeno de la evolución. Como dice Ayala ${ }^{58}$, el argumento central de la teoría de la evolución de Charles Darwin es la presencia de la variación genética según su propio razonamiento: deben existir variaciones en la naturaleza que son favorables o útiles de algún modo para el propio organismo en su lucha por la existencia. Este conjunto de variantes adaptativas en los organismos de la misma especie es lo que se suele llamar genepool o acervo genético. Este acervo genético es cuantificable atendiendo a la frecuencia de las variantes alélicas existentes. Si se diese una sola variante o gen $\mathrm{M}$, no podría existir la variación o evolución. $\mathrm{Si}$ existe otra variante $\mathrm{N}$ o alelo de $\mathrm{M}$, se presenta la posibilidad de que una variante alternativa se imponga sobre la otra si es más ventajosa para la adaptabilidad al ambiente y se reproducirá y continuará con más frecuencia que la otra. A ésta última llama Charles Darwin adecuación que se mide con la eficacia biológica. Esta frecuencia de reproducción o ritmo evolutivo supone, dice Aya$\mathrm{la}^{59}$, dos mecanismos: la presencia de las variantes genéticas y el proceso sexual recombinante para la mutación.

La selección artificial llevada a cabo desde antiguo por agricultores y ganaderos con objetivos comerciales es una demostración más de la variabilidad genética contenida en una población de individuos de la misma especie. Siguiendo las leyes mendelianas se ha conseguido una gran variedad de plantas y animales considerando una variante favorable determinada.

Sin embargo, Charles Darwin no supo explicar el origen de esta variabilidad genética. Ayala ${ }^{60}$ expone el proceso que puede dar lugar a la impresionante variación genética que existe en cada especie y la enorme diversidad de especies.

\footnotetext{
57 Ayala, F. J., La Teoría de la evolución, o.c. p. 61.

58 Ayala, F. J., «The Evolution of Life: An Overview», Evolutionary and Molecular Biology o.c. p. 36.

59 Ayala, F. J., La Teoría de la Evolución, o.c. p. 67.

60 Ayala, F. J., La Teoría de la Evolución, o.c. p. 75 y «The Evolution of Life: An Overview», Evolutionary and Molecular Biology, o.c. p. 38.
} 
El proceso por el que se originan nuevos alelos es llamado mutación ${ }^{61}$. La herencia, según Ayala, es un proceso conservador, la secuencia de nucleótidos del DNA se reproduce fielmente durante la duplicación, pero si éste fuese un proceso absolutamente fidedigno no tendría lugar la evolución. Durante la replicación del DNA ocurren errores de trascripción y mutaciones azarosas que se transmiten a las células hijas que difieren de las parentales en la secuencia de nucleótidos o en el número de ellos. Estas mutaciones son génicas o cromosómicas. Las génicas o puntuales son las que afectan a uno o a unos pocos nucleótidos en un trozo o gen de la cadena de DNA. Las cromosómicas afectan a muchos nucleótidos y, por tanto, a muchos genes, a su número, organización y en igual sentido a los cromosomas. De este modo simplificado clasifica el profesor Ayala ${ }^{62}$ las mutaciones cromosómicas:

- Cambios en el número de genes presentes en los cromosomas: a) Deficiencia o delección. b) Duplicación.

- Cambios en la situación de los genes en los cromosomas:

a) Inversión. b) Translocación.

- Cambios en el número de cromosomas:

a) Fusión. b) Fisión. c) Aneuploidia.d) Haploidía y poliploidía.

La mutación génica tiene lugar cuando la secuencia de nucleótidos del DNA es alterada por sustitución, inserción o pérdida de uno o varios nucleótidos. Lo más importante en nuestro caso es la relación que guarda la mutación génica con la evolución. Como dice Ayala ${ }^{63}$, las consecuencias de una mutación pueden pasar de inapreciables a letales. Si una sustitución de un nucleótido no daña la función esencial de una proteína es posible que el daño sea leve, en caso contrario puede ser drástico.

Según Ayala ${ }^{64}$, las variantes genéticas de una población ya han sido objeto de selección natural y están presentes porque mejoran la adaptación de sus portadores y por esto las variantes perjudiciales con respecto a un ambiente determinado ya han sido eliminadas. Especifica Ayala ${ }^{65}$, que las mutaciones recientes son perjudiciales en su mayoría. Sin embargo, una nueva alteración puede incrementar la adaptación del organismo a un ambiente y ser beneficiosa ${ }^{66}$.

Las mutaciones génicas se pueden producir, como se ha dicho con anterioridad, espontáneamente por simple error en la codificación secuencial o por la intervención del hombre en la selección artificial en plantas y animales o por la influencia de radiación de alta frecuencia, rayos ultravioleta, rayos Röngent, radiación nuclear o exposición a ciertos mutágenos químicos.

${ }^{61}$ Concepto conocido y estudiado por A. Weisman, expuesto por S. Wright inicialmente y con posterioridad por T. H. Morgan.

62 Dobzhansky, Ayala, Stebbins, Valentine, Evolución, o.c. pp. 58-59.

63 Ayala, F. J., La Teoría de la evolución, o.c. p. 81.

64 Ayala, F. J., Ibidem.

65 Ayala, F. J., Ibidem.

66 Ayala, F. J., La teoría de la Evolución, o.c. p. 82. 


\section{CuANTIFICACIÓN DE LA VARIABILIDAD GENÉTICA}

Los métodos tradicionales hacen posible el estudio de los genes que son variables, pero no de los que no lo son y, por esto, impiden el cálculo de los genes que son polimórficos. Dos avances, según Ayala ${ }^{67}$, han resuelto esta dificultad. El primero es conceptual: el descubrimiento de que los genes codifican la síntesis de proteínas por lo que la variación de la secuencia de aminoácidos de una proteína refleja variación también en el gen que la codifica. El otro avance de carácter técnico que permite medir la variación genética es la electroforesis en gel, mediante el examen de la movilidad electroforética de cada una las proteínas estudiadas. Los resultados del estudio electroforético o enzimogramas, como una primera aproximación, se han visto confirmados con las técnicas de secuenciación del genoma a gran escala.

Aunque la tasa de mutación es generalmente baja, las mutaciones ocurren continuamente en las especies naturales puesto que existen muchos individuos de cada especie y muchos genes en cada individuo. En el ser humano, por ejemplo, el análisis de 71 genes ha demostrado que el 28 por ciento de ellos (20 de los 71) son polimorfos y que de promedio el 6,7 por ciento de los individuos son heterocigóticos para cada gen. Esta abundante variación genética, debida a la mutación, da lugar a una amplia oportunidad para la evolución, especialmente cuando surge una nueva situación ambiental a la que las poblaciones son capaces de adaptarse como puede ser el caso de los antibióticos y los pesticidas.

Otra implicación importante de la abundancia de la variación genética, continúa Ayala ${ }^{68}$, en organismos de reproducción sexual, con excepción de los gemelos monocigóticos, es que no existen individuos genéticamente idénticos ni en el pasado, ni en el presente, ni en el futuro. Dado un individuo heterocigótico en 6,7 por ciento como es el ser humano, si se supone que tiene 30.000 genes de promedio, sería heterocigótico en 2.010 genes y tendría la potencialidad de producir $2^{2010}$ clases de gametos diferentes, número inmensamente mayor que el número de átomos del universo; de aquí, la imposibilidad de encontrar dos individuos genéticamente idénticos. Esta es la base biológica, dice Ayala, de la individualidad humana.

Para Ayala ${ }^{69}$, la dinámica del cambio genético se fundamenta en el principio de que la herencia no cambia por sí misma la frecuencia del cambio genético, principio recogido en la ley de Hardy-Weinberg que establece matemáticamente el equilibrio genético de una población: la frecuencia genética permanece constante de generación en generación. Esta ley tomada taxativamente haría imposible la evolución. En la realidad siempre habrá causas perturbadoras que impiden su cumplimiento. La ley de Hardy-Weinberg siempre está sometida

67 Ayala, F. J., Origen y evolución del hombre, o.c. p. 32.

68 Ayala, F. J., Origen y evolución del hombre, o.c. pp. 35-38.

69 Ayala, F. J., "The evolution of Life: An Overview», Evolutionary and Molecular Biology o.c. p. 39. 
a cuatro procesos de cambio: mutación, migración, deriva genética y selección natural.

La mutación es un proceso muy lento, su promedio es bajo. La migración o flujo genético tiene lugar cuando individuos de una población emigran a otra y se entrecruzan con sus miembros. Otro fenómeno que impulsa el cambio genético es la llamada deriva genética (drift) o cambio puramente aleatorio debido a errores de muestreo. De estos cuatro procesos el más importante, desde el punto de vista de la evolución, es la selección natural.

\section{El PROCESO DE LA SELECCIÓN NATURAL}

El papel predominante en la historia evolutiva es, sin duda, el de la selección natural, concepto protagonista en la teoría darwiniana. Como la mutación, inmigración y deriva genética, dice Ayala ${ }^{70}$, son procesos aleatorios con respecto a la adaptación y a la supervivencia que se origina, es necesario que sean controlados por la selección natural, de lo contrario, podría ocurrir que, si estos fuesen los únicos procesos de evolución, la organización de los seres vivos se desintegraría de forma gradual En este sentido, la selección natural cuida de modo continuado la organización de los organismos vivos en orden a la propia supervivencia. Literalmente escribe C. Darwin:

Esta conservación de las variaciones y diferencias individuales favorables y la destrucción de aquellas que son nocivas, es lo que he llamado selección natural o supervivencia de los más aptos ${ }^{71}$.

Es evidente, que el concepto de selección natural lo obtiene C. Darwin por analogía: si el hombre selecciona los mejores, de igual modo lo puede hacer la naturaleza. Sin embargo, Darwin es consciente de las dificultades que encuentran algunos en el concepto de selección y él trata de resolverlas ${ }^{72}$. Unos dicen: la selección natural induce la variabilidad. A lo que responde C. Darwin: la selección natural lo único que implica es la conservación de las diferencias individuales que presenta la naturaleza y son beneficiosas para el ser en su propio ambiente. Otros aducen que la selección natural supone elección consciente de los animales y, por tanto, no es aplicable a las plantas. Nadie se extraña, dice al autor, de que los químicos hablen de afinidades electivas entre los diversos elementos, ni se le ocurre pensar que un ácido ha escogido la base para combinarse preferentemente. Algunos afirman que la selección es como un poder activo o divinidad. A lo que se puede contestar: el movimiento de los planetas se explica muy bien acudiendo a la atracción de la gravedad y todos entienden lo que se pretende decir. Dice C. Darwin, que es difícil evitar la personificación de la naturaleza; por naturaleza entiende la acción agregada de muchas fuerzas

70 Ayala, F. J., La Teoría de la Evolución, o.c. p. 107.

71 Darwin, C., Origen de las especies, o.c. p. 94.

72 Darwin, C., Origen de las especies, o.c. pp. 94-96. 
naturales y por leyes, la serie de sucesos que hemos averiguado por nosotros mismos.

Insiste, aún más, C. Darwin en la aclaración del concepto de selección natural. Comprenderemos mejor, dice, el curso de la selección, tomando como un ejemplo un país que sufre algún tipo de cambio físico como es el clima. El número proporcional de sus habitantes sufrirá un cambio y algunas especies se extinguirán probablemente. Aun sin tener en cuenta los efectos del cambio de clima, cualquier cambio en las proporciones numéricas de sus habitantes afectaría severamente a los otros. Si se trata de un país abierto, inmigrarán a él nuevas formas de vida y perturbarán sus relaciones. Es poderosa la influencia de un solo árbol o mamífero introducido en una nueva población.

Para C. Darwin, si con el arte se consigue alcanzar una gran diferencia al cultivar diversas variedades, en el estado silvestre en el que unos árboles tienen que luchar con otros árboles y con diversos enemigos, es seguro, que esas diferencias fijarán la variedad que sobrevivirá y permanecerá, si el color blanco sobre el negro, la piel lisa sobre la rugosa etc.

Es muy importante y digna de considerar la aclaración del Dr. Ayala al concepto de selección de C. Darwin. Ya, el propio Darwin señala el uso restrictivo que hace de la expresión lucha por la existencia. (...) me valgo de esta expresión en un sentido amplio y metafórico ${ }^{73}$. Sentido que explicita Ayala:

La lucha por la existencia de que habla Darwin no es, necesaria ni generalmente, un combate cuerpo a cuerpo del que sólo el más fuerte sobrevive, sino una competición por recursos limitados en la que los individuos más eficaces en obtener comida, espacio vital y en reproducirse resultan favorecidos. Los individuos más agresivos, aun cuando sean los más fuertes, no serán favorecidos por la selección natural si entran en peleas que, frecuentemente, terminan en daño grave o muerte. Las variantes genéticas favorecidas por la selección natural no son necesariamente las que producen músculos superdesarrollados, sino las que incrementan la supervivencia y la producción de hijos. En los hombres, al igual que en los demás organismos, los que sobreviven y dejan más descendientes son, generalmente, los pacíficos y mansos de espíritu, no los guerreros y conquistadores ${ }^{74}$.

Esta normal competición por recursos limitados ocurre con frecuencia en la naturaleza entre insectos y plantas y en el mismo ser humano, pero no debe interpretarse con intenciones de carácter marxista como el fundamento natural de la lucha de clases, idea introducida por H. Spencer a disgusto del propio C. Darwin.

Según Ayala ${ }^{75}$, la expresión selección natural fue introducida por C. Darwin para referirse al sesgo o promedio reproductivo que favorece algunas variantes heredadas sobre otras. El concepto moderno de selección natural es el mismo

73 Darwin, C., El origen de las especies, o.c. p. 77.

74 Ayala, F. J., Origen y evolución del hombre, o.c. p. 60.

75 Ayala, F. J., «The evolution of life: An Overview», Evolutionary and molecular Biology, o.c. p. 40 y en La teoría de la Evolución, o.c. pp. 105-107. 
de C. Darwin, pero expresado con más precisión en términos matemáticos como promedio estadístico. La teoría matemática permite medir la selección, especificar las condiciones y predecir el resultado. La medida para cuantificar la selección natural es llamada en ingles fitness, eficacia biológica o adaptación en castellano.. No es igual eficacia que adaptación pero están correlacionadas y caminan juntas, pero no han de confundirse. La selección incrementa una mejor adaptación que conlleva una mayor eficacia biológica. Eficacia o valor adaptativo no es lo mismo que adaptación. Una eficacia biológica excesiva puede llevar a la extinción de la propia especie y entonces no se podría hablar de adaptación, como es el caso del incremento de eficiencia de un depredador en capturar presas; éste tendría una mayor eficacia biológica que los menos eficientes. Pero si el depredador llega a ser excesivamente eficiente, puede provocar la extinción de la especie de la presa y de la propia especie. Siguiendo esta reflexión de Ayala ${ }^{76}$ se puede pensar que la extinción de muchas especies en el pasado fue debida a la propia selección natural. No obstante, eficacia y adaptación deben ir siempre juntas, de lo contrario, afirma el autor, la vida en la Tierra se hubiera extinguido hace tiempo. Esta indicación de Ayala nos lleva a creer que la adaptación nunca es completa, admitidos los continuos cambios en el ambiente.

Es muy importante saber que el proceso de la selección natural es indefinido porque los ambientes sufren frecuentemente cambios, no sólo físicos como el clima, sino biológicos como pueden ser los otros organismos que interactúan: depredadores, parásitos, competidores, y el organismo ha de estar adaptándose en forma de feed-back continuado.

La medida de esta eficacia o adaptación se puede calcular de dos modos: como valor absoluto o como valor relativo. Los evolucionistas, dice Ayala ${ }^{77}$, prefieren usar el valor relativo de eficacia por ser matemáticamente más conveniente: $\mathrm{S}=1-\mathrm{w}^{78}$. La teoría matemática de la selección natural es aplicable en muchos casos como puede ser la llamada sobredominancia o heterocigosis que tiene en cuenta la superioridad de los heterocigotos.

76 Ayala, F. J., La Teoría de la Evolución, o c. p. 118.

77 Ayala, F. J., La Teoría de la Evolución, o.c. p. 108.

78 Ayala utiliza algunos ejemplos muy concretos para explicar cómo se investigan los efectos genéticos de la selección natural y su cuantificación. Atendiendo a la relación mutación-selección: si una población está constituida por individuos homocigóticos AA, BB y heterocigóticos $\mathrm{AB}$, y si los homocigóticos $\mathrm{AA}$ y los heterocigóticos $\mathrm{AB}$ tienen mayor eficacia que los homocigóticos BB, quiere decir que éstos últimos dejan menos descendientes y serán eliminados de forma gradual. En realidad, un gen menos eficaz o si es deletéreo, nunca será eliminado completamente. Existe la frecuencia de equilibrio dinámico que se da cuando el número de nuevos alelos producidos por mutación sea igual al número eliminado por selección. Si la tasa de mutación es U, la frecuencia de equilibrio para un alelo que causa una enfermedad letal es la raíz cuadrada de U. De la consideración de lo anterior, asegura el profesor Ayala, se derivan consecuencias prácticas muy importantes como es el caso de ciertas enfermedades humanas. 


\section{Modalidades de la SELECCión natural}

Hay dos modos de estudiar la selección natural, según Ayala ${ }^{79}$ : primero, como proceso genotípico, conociendo las frecuencias génicas como se ha indicado en páginas anteriores; segundo, con el análisis de los fenotipos o características observables de los individuos; dos formas complementarias. El estudio de los caracteres fenotípicos se realiza a través de la llamada distribución normal o curva de Gauss utilizada en estadística matemática. Es también importante conocer la varianza o dispersión para comprobar si la distribución se concentra o no alrededor de la media. Otros valores que se pueden considerar juntamente son la mediana y la moda.

T. Dobzhansky y Ayala ${ }^{80}$ distinguen varios modos de selección natural: normalizadora o estabilizadora, direccional, diversificadora, sexual.

Un tipo de selección natural que favorece a los individuos con fenotipo de valor medio y selecciona en contra los de valor extremo es la llamada selección normalizadora o estabilizadora ${ }^{81}$. En ésta, los fenotipos permanecen constantes de una generación a otra. Otro resultado de la selección estabilizadora es el de los organismos llamados fósiles vivos que mantienen su fenotipo y constitución genética estables y similares al de sus antepasados de hace millones de años. T. Dobzhansky ${ }^{82}$ et alii se preguntan ¿por qué enfermedades como la fenilcetonuria y el albinismo permanecen en la mayoría de las poblaciones humanas? La hipótesis más sencilla es: aunque surgen por mutación de forma repetitiva, la selección natural normalizadora impide su acumulación.

A veces, dice Ayala ${ }^{83}$, la distribución de genotipos se orienta en una dirección particular, selección direccional, tal es el caso de la selección artificial y cuando las circunstancias físicas y biológicas del ambiente cambian. Este tipo de selección fue el que utilizó C. Darwin para expresar el significado de la selección natural, a juicio de T. Dobzhansky ${ }^{84}$.

La selección diversificadora es otra modalidad de selección natural. Es la que puede favorecer a dos o más fenotipos a la vez en un mismo ambiente. Un ambiente nunca es homogéneo. Ayala ${ }^{85}$ lo describe como un mosaico formado por sub-ambientes más o menos heterogéneos. Hay heterogeneidad con respecto al clima, los recursos alimenticios y el espacio vital. También puede ser

79 Ayala, F. J., La teoría de la Evolución, o.c. pp. 123-146 y «The Evolution of Life: An Overview», Evolutionary and Molecular Biology, o.c. pp. 41-42. Para un mejor conocimiento del tema puede consultarse el capítulo $4^{\circ}$ de Evolución, o.c. pp. 96-128.

80 Dobzhansky, Ayala, StTebins, Valentine, Evolución, o.c. pp. 96-128.

81 Ejemplo típico de este modo de selección es el de la mortalidad infantil, que aumenta en los niños recién nacidos con estatura o muy pequeña o muy grande, y disminuye en los de talla intermedia que se ven favorecidos.

82 Dobzhansky, Ayala, Sttebins, Valentine, Evolución, o.c. p. 105 y ss.

83 Ayala, F. J., La Teoría de la Evolución, o.c. pp. 126-131 y Evolución, o.c. pp. 121-124.

84 Dobzhansky, Ayala, StTebins, Valentine, Evolución, o.c. p. 122.

85 Ayala, F. J., La Teoría de la Evolución, o.c. p. 132 y «The Evolution of Life: An Overview», Evolutionary and Molecular Biology, o.c. pp. 41-42. 
temporal (día o noche, estaciones del año) y espacial (diferentes áreas.) No hay un plan único que prevalezca en la naturaleza, asegura Ayala ${ }^{86}$.

Otros modos de selección natural son la selección sexual y la familiar cuyo estudio se intensifica por día. La primera se distingue por la atracción entre los dos sexos en orden a la reproducción. Ambos se parecen mucho morfológicamente menos en los caracteres sexuales y ciertos otros aspectos del propio sexo, que muestran un marcado dimorfismo tales como mayor tamaño y fuerza, colores brillantes, prominentes astas etc., que se dan en un solo sexo, visibles para los depredadores y, por tanto, menos ventajosos para sus portadores. Estas desventajas no pueden ser favorecidas por la selección natural, problema que ya advirtió C. Darwin, como escribe Ayala, y tuvo la habilidad de dar una solución. C. Darwin concluyó que tales caracteres aparecen como resultado de la selección sexual:

Depende esta forma de selección, no de una lucha por la existencia con relación a otros seres orgánicos o a condiciones externas, sino de la lucha entre los individuos de un sexo, generalmente entre los machos por la posesión del otro sexo ${ }^{87}$.

Posteriormente añade:

Así sucede, creo yo, que cuando los machos y hembras de cualquier animal tienen los mismos hábitos de vida, pero se diferencian en estructura, color o adorno, semejantes diferencias han sido principalmente causadas por la selección sexual ${ }^{88}$.

En este mismo sentido se pronuncia Ayala ${ }^{89}$. Aunque es cierto que estas características pueden ser menos ventajosas en ciertos aspectos ya señalados en relación con otras especies, pero quedan justamente compensadas por la selección sexual en otras como el aumento de atractivo para el otro sexo dentro de la propia especie, talla, agresividad y rango jerárquico de fuerza que favorecen el apareamiento y aumentan la reproducción.

Otro problema para la selección natural darwiniana es el altruismo de los animales. Aparentemente el gen altruista pierde eficiencia genética, mientras el egoísta se beneficia a costa del desgaste de aquel. Parece que la selección natural debiera favorecer el comportamiento egoísta y eliminar el altruista. Ayala $^{90}$, siguiendo a W. Hamilton y a R. Trivers ${ }^{91}$, lo resuelve con el concepto de selección familiar, es decir, cuando se tiene en cuenta a los parientes al evaluar la eficacia biológica. Así lo explica:

\footnotetext{
86 Ayala, F. J., La Teoría de la evolución, o.c. p. 132.

87 Darwin, C., El origen de las especies, o.c. p. 102.

88 Darwin, C., El origen de las especies, o.c. p. 104.

89 Ayala, F. J., La Teoría de la Evolución, o.c. pp. 135-136.

90 Ayala, F. J., La Teoría de la Evolución, o.c. pp. 137-138.

91 Pueden consultarse Hamilton, W., «The genetical evolution of social behavior», Journal of Theoretical Biology, 1964, 7: 1-52 y de TRIVERs, R., "The evolution of reciprocal altruism», Quaterly Review of Biology, 1972, 46: 35-57.
} 
La selección natural favorece la multiplicación de genes que aumentan el éxito reproductivo de sus portadores, pero no todos los individuos que poseen un gen dado necesitan tener un éxito reproductivo mayor; es suficiente con que, de promedio, se reproduzcan más eficazmente (...) Un gen que determina el altruismo paternal es favorecido por la selección natural siempre que el beneficio que reciban los hijos sea el doble o más de los perjuicios que le resultan al padre (...) Por ejemplo, un gen que incita al altruismo será favorecido por la selección natural si la muerte del padre altruista salva la vida de dos o más de sus hijos. Los genes paternos aumentarán en frecuencia en la población más rápidamente que genes alternativos que no promuevan el altruismo (...) Naturalmente, el comportamiento altruista no causa siempre, ni siquiera en general, la muerte del altruista ${ }^{92}$.

El llamado altruismo recíproco que se da entre grupos de individuos sin parentesco, también puede explicarse por selección natural. Tal conducta suponía una dificultad para admitir la explicación darwinista. La selección de grupos actúa de diferente modo que la selección de individuos. La solución de Ayala $^{93}$ es: si una colonia se reproduce excesivamente y agota los recursos ambientales, trae consigo su propia extinción. Esto no tendría lugar si dicha colonia restringe el crecimiento de la población sólo al posible en un ambiente dado. En este caso, sus genes perdurarían en la especie. No sería igual en una colonia egoísta que no limita su reproducción y tendría más probabilidad de extinguirse rápidamente.

En el comportamiento recíproco es menor el coste para el gen altruista y está compensado, como dice Ayala ${ }^{94}$, por los beneficios que recibe de la actitud solidaria de sus vecinos. Este altruismo recíproco es el que se da, por ejemplo, en las hormigas, abejas, avispas y en el uso de centinelas en grupos de aves y mamíferos. E. Mayr también aporta ideas interesantes sobre el altruismo de los animales ${ }^{95}$.

\section{LA SELECCIÓN NATURAL ES UN PROCESO CREADOR}

Para Ayala $^{96}$, la selección natural no es exclusivamente un tamiz que criba y anula las variantes que pueden perjudicar la adaptación de los organismos a sus ambientes y retiene las útiles. No es un proceso puramente negativo que sólo elimina lo desfavorable. Literalmente dice Ayala:

(...) La evolución puede considerarse un proceso creador en un sentido preciso parecido al que se atribuye al artista que no crea el lienzo o los colores,

92 Ayala, F. J., Origen y evolución del hombre, o.c. p. 83.

93 Ayala, F. J., Origen y evolución del hombre, o.c. p. 85.

94 Ayala, F. J., La Teoría de la Evolución, o.c. pp. 138-139.

95 MaYr, E., Así es la Biología, Edt. Debate, 2005, pp. 269-289.

96 Ayala, F. J., La Teoría de la Evolución, o.c. pp. 140-142. y «Reflexiones sobre la evolución como proceso creador», «Arbor», 1994, n 588, pp. 9-23. 
pero sí el cuadro. La evolución ocurre como resultado de la interacción de dos procesos componentes: la mutación genética, que es un proceso aleatorio y la selección natural, que es un proceso determinístico. Es la confluencia del azar y la necesidad la que determina el carácter creativo de la evolución. El azar y la necesidad están profundamente engranados en un proceso que ha creado las entidades más complejas e interesantes del universo, los organismos; y entre ellos el hombre, capaz de pensar y amar, y de reflexionar sobre el proceso de la evolución que le ha creado ${ }^{97}$.

Este carácter creativo de la selección natural capaz de generar novedad, lo ilustra Ayala ${ }^{98}$ con unos ejemplos que dan mayor claridad a su significado ${ }^{99}$. Además de la ya conocida analogía del pintor, Ayala refiere otro símil de la selección natural: los monos mecanógrafos. Algunos críticos de la selección natural dicen que este proceso se parece a unos monos que golpeando las teclas de una máquina de escribir de forma casual nunca escribirían El origen de les especies; no lo conseguirían aunque invirtiesen millones de años. Esto sería de este modo, explica Ayala ${ }^{100}$, si actuara sólo la mutación al azar, pero al considerar el proceso no aleatorio de la selección natural que elige las mutaciones y combinaciones que tienen sentido, la analogía se hace posible. Ayala afina su pensamiento al respecto y el significado de esta analogía:

(...) No necesitamos llevar la analogía de los monos muy lejos, ya que ninguna analogía es completamente satisfactoria, pero la cuestión que hay que aclarar no es que la evolución sea el resultado de puros procesos al azar, sino que existe un proceso de selección que escoge combinaciones adaptativas, simplemente por el hecho de que se reproducen de forma más eficaz. Estas combinaciones adaptativas constituyen, a su vez, nuevos niveles de organización sobre los que la mutación (azar) más la selección (dirección) operan a su vez en un proceso que se continúa de forma indefinida (...) los eventos posteriores actúan sobre resultados anteriormente obtenidos ${ }^{101}$.

Una última idea añade Ayala ${ }^{102}$ que demarca aun mejor su definición de selección natural: la selección es oportunista. Significa que la selección natural no trata de producir clases predeterminadas de organismos sino organismos que estén adaptados a su entorno. Por esta razón, las características que la selección escoge dependen de las que están presentes en un momento y lu-

97 Ayala, F. J., «Reflexiones sobre la evolución como proceso creador», «Arbor», o.c. p. 9.

98 Ayala, F. J., La Teoría de la Evolución, o.c. pp. 141-144.

99 En un cultivo e.c. de Escherichia coli, se producirán ciertas mutaciones espontáneas del orden de 20 en 2000 millones de bacterias, las cuales serán resistentes a la estreptomicina si se añaden unas gotas de ésta al cultivo. Es evidente, que morirá la mayoría de la población bacteriana excepto 20 de las bacterias portadoras de mutaciones que comenzarán a reproducirse, pero con la particularidad que no serán sensibles a la estreptomicina. Esto significa, para Ayala, que lo que era tremendamente improbable se convierte en un resultado común que no puede producirse por azar.

100 Ayala, F. J., La Teoría de la Evolución, o.c. p. 142.

101 Ayala, F. J., La Teoría de la Evolución, o.c. p. 143.

102 Ayala, F. J., La Teoría de la Evolución, o.c. p. 145. 
gar determinados. Definitivamente, los organismos o responden a cada desafío ambiental con adaptaciones apropiadas o se extinguen. Es posible que estas adaptaciones a un mismo ambiente, continúa Ayala ${ }^{103}$, ocurran de distinto modo en cada selección.

\section{OPOSICIÓN Y ALTERNATIVAS}

Pese a la oposición que presentan ciertos biólogos, J. A. Endler (1984), Bechler (1989), Pearse (1987), P. Jaisson (1993) y otros ${ }^{104}$ al concepto de selección natural porque les parece que no satisface las exigencias previstas por los neodarwinistas, no obstante, la selección natural, tal como la concibe el profesor Ayala, constituye una teoría coherente que explica con claridad y rigor científico el proceso evolutivo como se lo propone la nueva Biología, aunque hoy por hoy, presente aspectos discutibles que serán objeto de controversia. Existen alternativas al darwinismo como son la Teoría Neutral de Motoo Kimura, la Simbiogénesis de Lynn Margulis y el Saltacionismo de Stephen Jay Gould.

\section{Origen de las especies. Concepto de especie. Mecanismos de especiación}

Es bien conocida por todos los biólogos la importancia del papel que desempeña la especie en la biología evolutiva. El empeño radical de C. Darwin fue dar una explicación causal natural del origen de la gran diversidad de especies vegetales y animales y del cambio en los propios organismos.

La incompatibilidad del concepto platónico-aristotélico de especie con la teoría evolutiva por aquello de que no hay especies inmutables en la evolución por considerarse aquella de carácter fijista e inmóvil, ha provocado en las últimas décadas una cascada de agudas discusiones entre biólogos y filósofos sobre el verdadero concepto de especie biológica. Según J. Cracraft, las definiciones generalmente propuestas se distribuyen en dos grupos en los que unas revisten carácter observacional y otras teórico. Todas son objeto de discusión como señala Alfredo $\operatorname{Marcos}^{105}$ que hace un análisis de los diversos criterios adoptados por los biólogos.

103 Ayala, F. J., La Teoría de la Evolución, Ibidem.

104 Puede consultarse en Falgueras, I., «Breve examen científico y filosófico de la teoría de la evolución», Espíritu, o.c. pp. 111-118.

105 Marcos, A.. «Sobre el concepto de Especie en Biología,» La Mediación de la Filosofía en la construcción de la Bioética, F. Abel y Camino Cañón, Editores, Universidad Pontificia de Comillas, Madrid, 1993, pp. 43-59. Estos criterios son: el tipológico, operacionalista, biológico, ecológico, evolutivo, genético, nominalista. Omitimos su descripción detallada y comentario por razones de extensión y nos llevaría lejos del pensamiento del profesor Ayala. Puede consultarse también el trabajo de J. Cracraft y el de O. E. Wiley en What the Philosophy of Biology is, o.c. pp. 29-300. Todas las definiciones hasta ahora propuestas por los investigadores 
Apoyado en la doctrina nominalista E. Mayr ${ }^{106}$ escribe, según Ayala, que la revolución conceptual más importante en biología es lo que él llama population thinking, conceptualización poblacional. Los organismos de reproducción sexual se asocian en poblaciones o demes en las que los individuos son interdependientes de modo que un individuo aislado no tiene sentido biológico porque sus genes no serían transmitidos a otros. Una población es una comunidad de procreación. La especie está constituida por todos los individuos capaces de, al menos en potencia, de tener descendientes comunes. Las especies no son entidades creadas o esencias inmutables, sino realidades dinámicas en continuo flujo. Las frecuencias de los genes varían de una población a otra de la misma especie.

De la doctrina de E. Mayr se deduce, a nuestro juicio, que si la especie biológica no es entidad esencial con características inmutables, ni el código genético es constante e idéntico en los individuos de una población, parece no haber más recurso que acudir al concepto de reproducción para distinguir una especie de otra y los individuos pertenecientes a la misma. Es obvio que Ayala se adhiere al concepto de especie de E. Mayr presentado con anterioridad: grupo aislado reproductivamente, concepto que adoptan los biólogos padres y defensores de la teoría sintética. Nuestro autor ${ }^{107}$, en principio, admite el concepto de especie tomado de la experiencia común que nos enseña a distinguir diferentes tipos de organismos. En esta experiencia, el criterio simple es el de similitud externa que nos lleva a identificar los miembros de una mima especie ${ }^{108}$. Pero a poco que se piense, dice Ayala, este criterio morfológico o tipológico resulta insuficiente porque en él subyace algo más que la mera apariencia física. Un galgo y un terrier son muy diferentes en su aspecto exterior y, sin embargo, ambos son perros porque pueden entrecruzarse y dar descendencia, en cambio, un perro y un gato no pueden reproducirse. A partir de esta consideración, expresa el autor la siguiente definición de especie: Las especies constan de grupos de individuos que son capaces de cruzarse entre sí pero no con individuos pertenecientes a otros grupos ${ }^{109}$.

Esta capacidad de entrecruzarse es la que determina que una especie sea una unidad evolutiva independiente. Mediante el cruzamiento, los cambios genéticos que se producen en los individuos de una especie se dispersan a todos los miembros del grupo pero no pasan a los de otra especie, es decir, el acervo

resultan incompletas y presentan dificultades todavía no resueltas. Joel Kracraft recoge un conjunto de definiciones de especie tomadas de diversos autores que se encuentran en la obra citada.

106 MaYr, E., «Animal Species and Evolution», Harvard University Press, 1963. Citado e interpretado por F. J. Ayala, «Evolución, tiempo y filosofía», «Arbor», o.c. pp. 58-62.

107 Ayala, F. J., La Teoría de la Evolución, o.c. 148-149.

108 Aristóteles diría que dos individuos pertenecen a la misma especie si participan de la misma esencia. Pero ¿qué es la esencia? Evidentemente no es un rasgo sino «algo más profundo». Estructura y organización propias. Zubiri, probablemente, diría que tiene «notas propias».

109 Ayala, F. J., La teoría de la Evolución, o.c. p. 149. 
genético se comparte por los componentes de la misma especie pero no por los de otra ${ }^{110}$.

Para el profesor Ayala, este aislamiento reproductivo es un criterio suficiente y claro para discernir si unos individuos pertenecen o no a la misma especie, pero presenta dificultades por dos razones que él mismo aclara ${ }^{111}$. La primera, por desconocimiento: no sabemos si individuos que viven geográficamente separados podrán entrecruzarse si se presenta la situación. Segunda: como la evolución es gradual, ignoramos el momento preciso en el que individuos que han convivido se separan y forman especies distintas. Se producen situaciones de divergencia intermedias difíciles de discernir como ocurre en los estadios de desarrollo, infancia, adolescencia y madurez, las estaciones del año etc. Se presentan igualmente ocasiones que no encajan bien en el criterio reproductivo como son las llamadas cronoespecies y especies clonales.

El concepto de especie utilizado por Ayala es aplicable a los organismos coetáneos pero no a los que han vivido en diferentes épocas. Ayala afirma:

Son considerados miembros de especies diferentes aquellos organismos de distintas épocas que difieren morfológicamente entre sí tanto como difieren organismos contemporáneos clasificados como especies distintas ${ }^{112}$.

La definición dada de especie se refiere a los organismos de reproducción sexual pero no a los que se reproducen por vía clonal o no sexual como los protozoarios. Para éstos, el criterio de clasificación es el morfológico, el genético o el fisiológico.

El criterio reproductivo de especiación implica, según Ayala ${ }^{113}$, la existencia de mecanismos o barreras biológicas que impiden el cruzamiento. Estos mecanismos o barreras biológicas que surgen entre organismos de distinta especie y que impiden el cruzamiento son los llamados mecanismos de aislamiento reproductivo.

Los evolucionistas clasifican estos mecanismos en dos grupos ${ }^{114}$ :

Precigóticos: Ecológicos, estacionales, conductuales, mecánicos y gaméticos. (Impiden la fecundación del óvulo).

Postcigóticos: Inviabilidad y esterilidad de los híbridos. (Actúan después de la fecundación).

Hacemos un breve resumen de las características más destacadas de los mecanismos de aislamiento reproductivo siguiendo la explicación del Dr. Ayala ${ }^{115}$ :

El aislamiento ecológico se da entre organismos que ocupan el mismo territorio pero viven adaptados a distintos nichos o habitats. No se distinguen

\footnotetext{
110 Ayala, F. J., Ibidem.

111 Ayala, F. J., La Teoría de la Evolución, o.c. p. 150.

112 Ayala, F. J., La Teoría de la Evolución, o.c. p. 152.

113 Ayala, F. J., La Teoría de la Evolución, o.c. p. 153.

114 Ayala, F. J., La Teoría de la Evolución, o.c. pp. 153-158. Origen y evolución del hombre, o.c. p. 99 y Evolución, o.c. pp. 173-179.

115 Ayala, F. J., La Teoría de la Evolución, o.c. pp. 153-158.
} 
morfológicamente pero están reproductivamente aislados. Un ejemplo típico puede ser el mosquito Anopheles del cual una especie vive en agua salobre, otra en agua dulce y otra en agua dulce estancada.

El aislamiento estacional hace que los organismos puedan madurar o florecer en diferentes estaciones o diversas horas del día.

El aislamiento conductual es debido a la falta de atracción entre ambos sexos. En el comportamiento sexual están involucrados gran variedad de estímulos como rituales de cortejo, táctiles, auditivos, que al estar ausentes impiden el cruzamiento. El aislamiento mecánico surge cuando los mecanismos genitales presentan desajustes que impiden la fertilización como pueden ser el diferente tamaño o la estructura.

El aislamiento gamético se da entre gametos de diferente especie. Aun cuando estén flotando unos junto a otros no se atraen, y sólo los de la misma especie se fertilizan entre sí. Suelen concurrir impedimentos físicos o químicos que no permiten la aproximación.

El aislamiento postcigótico se produce, una vez, formado el cigoto tras la fertilización, cuando los embriones no son viables o estériles y mueren antes del desarrollo como adultos o no dejan descendientes como en el caso de los híbridos.

\section{TEORÍAS Y MODELOS DE ESPECIACIÓN}

A juicio de Ayala: La cuestión del origen de las especies se centra en determinar el modo o proceso cómo se genera el aislamiento reproductivo entre poblaciones $^{116}$. Dos teorías se han propuesto para ello, según Ayala ${ }^{117}$, la incidental y la selectiva. La incidental considera que el aislamiento reproductivo es un subproducto incidental de la divergencia genética que se produce de forma gradual como consecuencia de su adaptación al entorno llegando el momento en que los acervos genéticos no son armónicos y no producen descendencia. La teoría selectiva pondera el aislamiento reproductivo como producto directo de la selección. Según Ayala ${ }^{118}$, ambas difieren en dos aspectos. La teoría selectiva afirma que los genes no pueden evolucionar de forma incidental (casual) sino por selección natural, y que el aislamiento reproductivo impone que las dos poblaciones convivan simpátridamente para que exista posibilidad de hibridación y ocurra la selección de genes que impide el apareamiento al ser baja la eficacia reproductiva. Asegura Ayala ${ }^{119}$ que ambas teorías son compatibles y

\footnotetext{
116 Ayala, F. J., La Teoría de la Evolución, o.c. p. 159.

117 Ayala, F. J., La Teoría de la Evolución, o.c. pp. 159-160.

118 Ayala, F. J., La Teoría de la Evolución, o.c. p. 160.

119 Ayala, F. J., La Teoría de la Evolución, Ibidem. Así lo expresa el autor:

(...) Con frecuencia, el curso de la especiación involucra los procesos postulados por ambas teorías. El aislamiento reproductivo se inicia como consecuencia de la divergencia genética que tiene lugar en poblaciones geográficamente separadas; pero es completado por
} 
pueden constituir dos etapas distintas del mismo proceso de cuya conjunción puede resultar un modelo general de especiación.

El modelo general de especiación expuesto, nos dice Ayala ${ }^{120}$, pude ocurrir de dos formas: Especiación geográfica y especiación cuántica.

La especiación geográfica coincide con el modelo general de especiación ya conocido. La especiación cuántica, saltacional o rápida tiene lugar cuando el primer estadio de la especiación, con la aparición de los mecanismos de aislamiento reproductivo postcigoticos que suele ser gradual y la divergencia genética puede durar miles o millones de generaciones, entonces, la especiación cuántica se realiza en cortos períodos de tiempo y en pocas generaciones. Un ejemplo de especiación cuántica es la poliploidía.

Otro modo de especiación es la llamada radiación adaptativa, cuyo concepto se expuso en páginas anteriores, para explicar la gran biodiversidad de ciertos parajes. Un ejemplo típico de radiación adaptativa es el de los pinzones de Darwin, que componen catorce especies distintas en las islas Hawai y las quinientas especies de Drosophila melanogaster en estas mismas islas.

Por último, añade Ayala ${ }^{121}$, para comprender mejor el sentido de la especiación y la evolución es útil cuantificar el cambio genético producido durante la especiación como se ha visto ya con anterioridad.

Conocidos el concepto de especie y el proceso de especiación, es necesario aclarar la distinción entre especie y raza o variedad. El concepto de especie ha quedado nítidamente definido por Ayala: las especies son grupos de individuos reproductivamente aislados entre sí. Las razas, según Ayala ${ }^{122}$, son poblaciones que han divergido genéticamente debido a su separación geográfica, pero no están reproductivamente aisladas.

De esta distinción de conceptos se deduce que razas diferentes pueden entrecruzarse y dejar descendencia, por tanto, no son genéticamente más diferentes ni son especies incipientes. Tendríamos que hablar mejor de simples variaciones que de razas para evitar la confusión.

\section{ReCONSTRUCCIÓN DE LA HISTORIA EVOLUTIVA}

Como dice Ayala ${ }^{123}$, la evolución es el proceso de cambio de los seres vivos en el curso de las generaciones. Este proceso implica cambio gradual, tanto en el genotipo (dotación genética) como en el fenotipo (resultado de la interacción del genotipo y ambiente.) Los cambios en el fenotipo no tienen consecuencias evolutivas, como se ha dicho con anterioridad, si no están fundamentadas en un

\footnotetext{
la selección natural directa de mecanismos de aislamiento reproductivo, una vez surgida de nuevo la oportunidad de apareamiento cuando los híbridos tienen baja eficacia biológica.

120 Ayala, F. J., Origen y evolución del hombre, o.c. pp. 104 y 109-110.

121 Ayala, F. J., El origen y evolución del hombre, o.c. 113-114.

122 Ayala, F. J., Origen y evolución del hombre, o.c. pp. 148-154.

123 Ayala, F. J., La naturaleza inacabada, o.c. pp. 67-69.
} 
cambio genético. Los caracteres adquiridos no se heredan al contrario de lo que afirmó Lamarck; sólo el genotipo es transmitido a las siguientes generaciones. El genotipo se considera como código de información de las instrucciones para el desarrollo ontogenético y es registro que almacena la información de la historia evolutiva de un organismo. El fenotipo es el resultado de la conformación de las estructuras morfológicas, fisiológicas y comportamentales del ser vivo con las pautas del genotipo en un conjunto de circunstancias ambientales. Siendo el genotipo código y registro de la historia evolutiva del ser vivo, es obvio que la Genética sea la base de la evolución y constituya su mejor explicación científica.

En efecto, la reconstrucción de la historia evolutiva se puede conseguir, en parte, con la aplicación de las conclusiones de las diversas disciplinas biológicas, pero al ser en sí muy limitadas, los resultados no son siempre satisfactorios ni dan evidencia suficiente sobre los hechos. Como hace notar Ayala: estas disciplinas estudian la conformación de los organismos a un nivel bastante alejado del genotipo ${ }^{124}$.

Es la Biología Molecular y, en concreto, la Genética Molecular con su enorme desarrollo en los últimos tiempos, la que estudia la historia evolutiva de los seres vivos, comparando ácidos nucleicos y proteínas, con resultados admirables por su precisión y elegancia, al tratar la información hereditaria muy cerca del genotipo, a diferencia de las otras ramas de la Biología. Al estar tan íntimamente relacionados ácidos nucleicos y proteínas se conocen como macromoléculas informativas.

Las proteínas reflejan fielmente la información hereditaria contenida en el DNA aunque, como dice Ayala ${ }^{125}$, este reflejo no es completo al ser redundante el código genético por lo que no siempre produce diferencias en proteínas, y además, no es exhaustivo porque más del 90 por ciento del DNA no interviene en la codificación de las proteínas. No obstante, a juicio de Ayala:

Estas macromoléculas son un instrumento informativo mucho más eficaz para el estudio de la historia de la evolución que la Anatomía comparada y las demás disciplinas que tratan de la conformación de los organismos a nivel más alejado de la información hereditaria ${ }^{126}$.

Esta información molecular ofrece dos notables ventajas: una, la información es cuantificable; otra, pueden compararse organismos muy diferentes.

Estas macromoléculas no sólo dan información sobre la cladogénesis (diversificación entre linajes) sino también sobre la anagénesis (cambio genético dentro del mismo linaje). Un ejemplo concreto usado en esta metodología macromolecular, según Ayala ${ }^{127}$, es el del citocromo $c^{128}$.

124 Ayala, F. J., La naturaleza inacabada, o.c. p. 68.

125 Ayala, F. J., Ibidem, p. 68.

126 Ayala, F. J., La naturaleza inacabada, o.c. p. 69.

127 Ayala, F. J., La naturaleza inacabada, o.c. p. 72.

128 El citocromo $\mathrm{C}$ es una proteína de la respiración celular existente en las mitocondrias de todos los organismos, desde las bacterias al ser humano. La secuencia de esta proteína consta de 104 aminoácidos. Si se compara el citocromo c del Maccacus rhesus y el del ser 
Gracias a las modernas técnicas introducidas por la Biología molecular, además de las clásicas, podemos reconstruir la historia evolutiva de los organismos con gran exactitud. Estos métodos, según Ayala ${ }^{129}$, permiten identificar la correspondencia filogenética de caracteres en distintos organismos.

La correspondencia cladogenética debida a la herencia desde un ancestro común es la llamada homología que se da, por ejemplo, entre los miembros anteriores del ser humano y los de las ballenas, perros y murciélagos, cuyos esqueletos están diseñados de acuerdo con un mismo modelo que es el ancestro común. La correspondencia en un carácter debido a una función determinada y no relacionada con ancestro común es la llamada analogía, como la que se da entre las alas de un ave y una mariposa; ambas surgen para cumplir una misma función, volar, pero no tienen estructura común heredada. Otro tipo de correspondencia es la seriada, que tiene lugar entre las estructuras que se repiten en un mismo organismo como los brazos y piernas en los seres humanos, las vértebras en los mamíferos, las ramas y hojas de un árbol. Otra homología es la convergente, cuando los descendientes se parecen más que los ancestros. La homología paralela implica que dos o más linajes han cambiado al unísono como la homología entre mamíferos placentarios y mamíferos marsupiales australianos y no se debe a un ancestro común sino a formas de vida similares.

Muy importante es la homología seriada en el nivel molecular entre genes derivada de duplicaciones genéticas ancestrales y que se conoce como paralogía, si se da entre las cadenas del mismo gen; cuando es entre genes de distintas especies es ortología. La homología en la misma proteína de diversas especies (ortología) es la que se utiliza en la construcción del árbol filogenético molecular en Biología evolutiva.

Desde antiguo se ha intentado clasificar a los seres de forma taxonómica, atendiendo a su semejanza morfológica ${ }^{130}$. Como esta semejanza exterior era muy limitada, se recurrió también a las filogenias cromosómicas. Las técnicas actuales de la Biología molecular con la ayuda de la Bioinformática constituyen hoy día el arma más poderosa para el estudio de los árboles filogenéticos.

\footnotetext{
humano encontramos que 103 de estos aminoácidos son idénticos excepto el 66 ( el del ser humano es una isoleucina y el del macaco es una treonina); en el caballo hay 12 diferencias si se compara con el hombre y 11 entre el caballo y el macaco. Con sólo esta información se puede concluir que las diferencias en la secuencia de aminoácidos del ser humano y del macaco debieron producirse en el ser humano después de escindirse éste del linaje del macaco. Conocido es el árbol filogenético basado en la secuencia de aminoácidos del citocromo $\mathrm{C}$ de 1967.Para una información más profunda puede consultarse La naturaleza inacabada, o.c. pp. 67-93.

129 Ayala, F. J., «The evolution of Life: An Overview», Evolutionary and molecular Biology, o.c. pp. $47-48$

130 Dobzhansky, Ayala, Stebbins, Valentine, Evolución, o.c. pp. 262-311.
} 


\section{Controversias acerca del proceso evolutivo. Visión de F. J. Ayala}

Debido a las dificultades que presenta la reconstrucción científica de los cambios evolutivos ocurridos durante millones de años, el Dr. Ayala ${ }^{131}$ fija su atención en aquellas cuestiones que siguen siendo motivo de debate científico a las que pretende dar solución desde la perspectiva de la moderna Biología evolutiva, y exponemos de forma sucinta.

\subsection{El reloj molecular}

La primera cuestión que plantea el autor ${ }^{132}$ es la validez y exactitud del reloj molecular. E. Zuckerkandi y L. Pauling fueron los primeros en proponer que si el ritmo de substitución de nucleótidos en la evolución es constante, podría servir de reloj molecular. Se ha observado que el número de diferencias de aminoácidos en una proteína en distintas especies es proporcional al tiempo transcurrido desde su separación de un ancestro común.

(...) Se necesita, en primer lugar, calibrar el reloj para una proteína dada (...) determinando el número de cambios acumulados desde que ocurrió un determinado suceso cuya datación es conocida ${ }^{133}$.

No se trata, ciertamente, de un reloj cronométrico exacto como el que usamos a diario sino estocástico, donde la probabilidad de que un cambio ocurra es constante. Según Ayala, las posibilidades del reloj molecular son ilimitadas puesto que cada gen o proteína constituye un reloj independiente, sin embargo, hay que considerarlo errático puesto que la variación real en la evolución del DNA es superior a la facilitada por el reloj molecular. Afirma Ayala ${ }^{134}$ que el uso más frecuente de la hipótesis del reloj molecular ha sido la reconstrucción de la historia evolutiva y con él podemos saber dos cosas: primera, si conocemos cuándo se produjo la escisión de las especies, podemos comprobar si el reloj molecular es correcto. Segunda, si se desconoce el momento de la separación de los linajes, el número de substituciones que han tenido lugar pueden servir para estimar el tiempo transcurrido. A juicio de Ayala $^{135}$, se debe tener precaución al utilizar la secuencia de una sola proteína o gen al hacer deducciones evolutivas. Mejor es promediar muchas proteínas y organismos, puesto que no existe evidencia de que el ritmo evolutivo de un gen o proteína sea el mismo en los diferentes linajes o sea constante a través del tiempo en el mismo linaje.

\footnotetext{
131 Ayala, F. J., La naturaleza inacabada, o.c. pp. 117-196.

132 Ayala, F. J., La naturaleza inacabada, o.c. p. 117.

133 Ayala, F. J., La teoría de la Evolución, o.c. p. 206.

134 Ayala, F. J., La naturaleza inacabada, o.c. pp. 116-119.

135 Ayala, F. J., La naturaleza inacabada, o.c. p. 137.
} 


\subsection{Microevolución y macroevolución}

En dos niveles diferentes se puede considerar la evolución de los organismos: el microevolutivo (nivel molecular) y el macroevolutivo (nivel fenotípico o morfológico.) Ambos tienen sus defensores y detractores en oposición. J. Monod es defensor acérrimo del primero y desemboca en un optimismo exagerado. Por el contrario, S. J. Gould condena la moderna teoría de la evolución como lo refiere Ayala ${ }^{136}$. Gould ha rectificado posteriormente y reconoce que la genética de poblaciones evolutiva no es errónea o inadecuada, aunque no lo es todo. La síntesis moderna, dice, es incompleta pero no errónea en su nivel. Que la teoría microevolutiva no es todo y que es incompleta es un punto en el que sólo se puede estar de acuerdo, responde Ayala.

El problema fundamental de esta cuestión es, si la evolución se desarrolla en forma puntual o gradual y si los mecanismos microevolutivos pueden evaluar el proceso macroevolutivo.

Los puntualistas (paleontólogos) defienden que la evolución morfológica procede a ráfagas y el cambio fenotípico se produce durante la especiación y luego pasan largos períodos de tiempo, millones de años, sin cambio fenotípico alguno. Por tanto, la macroevolución es independiente de la microevolución y autónoma. Los gradualistas consideran, por el contrario, que el cambio morfológico es un cambio, más o menos, gradual y no asociado estrechamente a la especiación. A juicio de Ayala ${ }^{137}$, esta discrepancia hay que resolverla empíricamente. En esta tesitura, el problema para el microevolucionista sería explicar la razón de que haya linajes que perduran durante millones de años sin cambio fenotípico notable. La respuesta se podría encontrar en la selección estabilizadora, aunque no existen pruebas empíricas.

La cuestión de si los procesos macroevolutivos pueden explicarse con los mecanismos microevolutivos, según Ayala ${ }^{138}$, parece resuelta afirmativamente, por lo menos en parte. Las macromutaciones que tienen lugar en Drosophila y otros organismos lo demuestran. En este sentido empírico, concluye el profesor Ayala ${ }^{139}$, la macroevolución y la microevolución no están desacopladas y son teorías compatibles. Los fenómenos macroevolutivos pueden interpretarse como resultado de procesos microevolutivos. Otra cosa es preguntarse si son reductibles unos a otros. La respuesta es negativa en el estado actual de nuestro conocimiento por lo que afirma $A_{y a l a}{ }^{140}$ : en sentido epistemológico, la macroevolución está desacoplada de la microevolución y es un campo autónomo de investigación evolutiva.

\footnotetext{
136 Ayala, F. J., La naturaleza inacabada, o.c. p. 140.

137 Ayala, F. J., Ibidem.

138 Ayala, F. J., La naturaleza inacabada, o.c. p. 146.

139 Ayala, F. J., La naturaleza inacabada, o.c. pp. 158-174.

140 Ayala, F. J., La naturaleza inacabada, o.c. p. 152.
} 


\section{3. ¿Selección natural o azar?}

Conocemos la definición de selección natural propuesta por Ayala: el proceso de reproducción diferencial de las variantes génicas alternativas. Según el autor, se ha tildado de circular a la definición de selección porque la conclusión está incluida en la premisa, o el definiendum en el definiens y de este modo, los más aptos son los que se reproducen más. Se reproducen más los más aptos, es decir, supervivencia de los supervivientes. Ayala ${ }^{141}$ argumenta que no tienen por qué ser circulares las definiciones de selección natural si se presentan bien. No siempre los más aptos son los que sobreviven, a veces, ocurre el efecto contrario cuando hay exceso de adaptación. Puede ocurrir que variantes adaptativas en un caso no lo sean en otro, sobre todo, cuando los ambientes cambian.

Otros se empeñan en afirmar que la selección natural es indemostrable empíricamente lo que es erróneo, como dice Ayala ${ }^{142}$. Existen pruebas empíricas suficientes de la actuación de la selección natural, como son las observaciones de laboratorio que realizó T. Dobzhansky con Drosophila pseudoobscura, en la que los cambios en ordenaciones cromosómicas eran atribuibles a diversas temperaturas, y el experimento llevado a cabo por Ayala y Sved con Drosophila para comprobar la eficacia media entre individuos homocigóticos y heterocigóticos. De estas premisas deduce Ayala ${ }^{143}$ :

1) Es cierto lo mucho que aún queda por hacer, sobre todo, en cuanto a determinar las interacciones adaptativas entre organismos y ambiente. 2) La interpretación de acontecimientos pasados sólo pueden corroborarse por analogía con hechos actuales. 3) La selección natural es un proceso explicativo demasiado fácil para todo conocimiento evolutivo, por lo que debemos ser cautos y probar la existencia de la selección natural en cada caso concreto, y no aceptarla sin más si no media una prueba empírica.

Paralela a la teoría evolucionista clásica fundamentada en el proceso por selección natural, surge en 1968 la llamada teoría neutral propuesta por el japonés Motoo Kimura. Esta hipótesis matemática, a juicio de Ayala ${ }^{144}$, es de gran contenido empírico, puede contrastarse con los hechos, y de ser correcta, serviría como hipótesis nula, es decir, de punto de partida para medir la exactitud del reloj molecular. Propone esta hipótesis, según Ayala ${ }^{145}$, que gran parte del cambio evolutivo en el nivel molecular no es debido a la selección natural sino a efectos estocásticos de la deriva genética, es decir, al azar. Esta teoría neutralista ha mostrado al ser contrastada, que sus predicciones no se ajustan a los hechos comprobados experimentalmente. Ayala concluye: la única hipótesis alternativa válida para dar cuenta del cambio evolutivo en el estado actual de nuestro conocimiento, es la selección natural como proceso no aleatorio.

\footnotetext{
141 Ayala, F. J., La naturaleza inacabada, o.c. pp. 155-158.

142 Ayala, F. J., La naturaleza inacabada, o.c. pp. 157-158.

143 Ayala, F. J., La naturaleza inacabada, o.c. p. 158.

144 Ayala, F. J., La naturaleza inacabada, o.c. pp. 158-152.

145 Ayala, F. J., La naturaleza inacabada, o.c. pp. 158-174.
} 


\subsection{Ingeniería genética y estabilidad de las especies}

Dos son los factores que rigen el desarrollo evolutivo: primero, la deriva genética, azar o la varianza en el muestreo de variantes alélicas de una generación a otra, y segundo, la selección natural que dirige tales variantes. En qué dirección, de entre las posibles alternativas, evolucionará una especie, lo determina la selección natural en cada caso concreto.

A juicio de Ayala:

(...) Las alternativas genéticas que resultan favorecidas en un caso particular dependen de las complejas interacciones entre los genes de un organismo dado, entre ese organismo y los demás de su misma especie y de especies diferentes, y entre los organismos y el medio ambiente. Por tanto, el resultado específico de la selección natural es a menudo difícil de predecir, dado que hay múltiples resultados posibles ${ }^{146}$.

Quiere decir que el complejo proceso de la selección natural mantiene estable la coadaptación del acervo genético de las especies activando los mecanismos de aislamiento reproductivo. Pero la genética molecular tiene a su disposición unos instrumentos poderosos como la hibridación e inserción de DNA que pueden variar la estabilidad genética de un organismo. Lo que Ayala $^{147}$ cuestiona es el éxito asegurado de estas nuevas técnicas. ¿Cuál es el destino probable del DNA insertado?. La respuesta, como es obvio, ha de ser múltiple:

$1^{\text {a) }}$ Debido a la coadaptación de los acervos génicos, es probable, que los materiales genéticos introducidos por medios artificiales en organismos superiores, resulten seleccionados negativamente y eliminados más temprano o más tarde.

$2^{\text {a) }}$ La inserción de DNA podría ser tolerada si no es genéticamente activo, es decir, si es neutro, pero es improbable que tenga mayores consecuencias evolutivas. No sabemos si podría acumularse convirtiéndose en una carga y tendría que ser seleccionado y eliminado porque supondría un gasto energético inútil.

$3^{\mathrm{a}}$ ) Aun cuando la introducción de un gen o más confiriese a la especie una propiedad beneficiosa, es difícil evaluar la probabilidad de que puedan ser aceptados por la selección natural. Es muy improbable que sea preservado, si no es con una intervención humana continuada, como ocurre en agricultura.

Contraejemplos se presentan en la hibridación y poliploidía, que aunque no son corrientes, tampoco son raros.

Se utilizan hoy técnicas de recombinación en la producción de alimentos, los llamados transgénicos. En todos estos procedimientos, predominantemente artificiales, advierte Ayala, no debe perderse de vista el peligro potencial de que una especie llegue a ser una plaga o un parásito eficiente.

146 AYALA F .J. La naturaleza inacabada, o.c. p. 176.

147 Ayala, F. J., La naturaleza inacabada, o.c. pp. 170-182. 


\section{Origen y eVolución del hombre según F. J. Ayala}

Cuando Ayala comienza su discurso biológico acerca del origen del ser humano se remonta al hecho de la evolución con estas palabras:

El origen evolutivo de los seres vivientes, incluyendo la especie humana, está hoy en día más allá de toda duda razonable. Aunque no se poseen todos los detalles del proceso, la historia evolutiva del hombre se conoce mejor que la de la mayoría de las demás especies vivientes. Y cualquier persona que quiera tomarse el esfuerzo de estudiar la evidencia, no puede dudar de que nuestros antepasados de hace millones de años no eran seres humanos (...) existe evidencia científica incontrovertible del hecho de la evolución humana ${ }^{148}$.

Colocada esta primera piedra, un breve remonte por la escala geológica nos puede llevar a una mejor comprensión del origen del hombre partiendo sólo de presupuestos científicos. Según el autor ${ }^{149}$, nuestra especie Homo sapiens sapiens subespecie de Homo sapiens, es de origen muy reciente y un advenedizo en la Tierra.

Nuestros parientes vivientes más cercanos son los antropoides que se clasifican así:

\begin{tabular}{|l|}
\hline Póngidos asiáticos: Gibón y orangután. \\
\hline Antropoides: Póngidos africanos: Chimpancé y gorila. \\
\hline Homínidos: Hombre. \\
\hline
\end{tabular}

De los homínidos, el único superviviente es el hombre.

Cuando se busca el eslabón perdido en la cadena evolutiva humana, puesto que es un proceso gradual, deben haber existido organismos intermedios entre el hombre y los antropoides. Según Ayala, siguiendo el paradigma admitido:

Aun cuando muchos detalles de la evolución humana son todavía desconocidos o hipotéticos, los jalones principales de los últimos cinco o seis millones de años están bastante bien confirmados. De manera esquemática están representados por las transiciones: Austrolopithecus africanus - Homo habilis - Homo erectus - Homo sapiens - Homo sapiens sapiens. ${ }^{150}$

Ayala se siente sorprendido por la singularidad humana y escribe:

(...) Una convicción fundamental en mi vida: que los humanos somos una especie animal, aunque seamos una especie animal muy particular, y diferente de todas las demás de manera radical, puesto que sólo los humanos tenemos las capacidades intelectuales que hacen posible la literatura, el arte,

148 Ayala, F. J., Origen y evolución del hombre, o.c. pp. 124-125.

149 Ayala, F. J., Origen y evolución del hombre, o.c. pp. 125-136.

150 Ayala, F. J., Origen y evolución del hombre, o.c. p. 141. 
la ciencia y la tecnología exuberante que, para bien y para mal, caracteriza a las sociedades contemporáneas ${ }^{151}$.

Pero reconoce:

(...) Es cierto que el descubrimiento del origen evolutivo de la humanidad no es suficiente para darnos a entender qué es el hombre pero proporciona el punto de partida necesario para ello ${ }^{152}$.

Su convencimiento es grande y explicita este punto de partida:

(...) Pero si queremos entender lo que somos y adónde vamos, debemos entender de dónde venimos, puesto que ello define nuestra realidad y delimita nuestras posibilidades. Es decir, lo humano, lo que nos distingue de otros seres vivientes y del resto del universo, sólo puede ser entendido como producto de la evolución. Nuestros antecedentes biológicos, aproximadamente de hace 3.500 millones de años, va desde las bacterias a animales muy primitivos, más tarde a los mamíferos, a los primates, a Lucy y, eventualmente, al Homo sapiens, nuestra especie. Nuestra historia biológica define y delimita lo que somos y lo que podemos $\operatorname{ser}^{153}$.

Para conocer la naturaleza humana, siguiendo estos criterios, es por lo que emprende el profesor Ayala ${ }^{154}$ el estudio de las semejanzas y diferencias entre el hombre y los antropoides que aquí se señalan con brevedad:

\section{Semejanzas anatómicas:}

El cuerpo humano está construido con arreglo al mismo plan general de los cuerpos de otros animales. La correspondencia hueso a hueso entre hombre y antropoides es impresionante. Se caracterizan ambos por ciertos rasgos comunes como son inmovilidad de las orejas, reducción del olfato, pérdida de pelos tácticos, existencia de un ciclo menstrual y ausencia de período estacional de cría, una sola cría por parto, gran cuidado maternal y dominancia de los machos adultos.

\section{Diferencias anatómicas:}

Postura erecta normal y constante de la columna vertebral en el hombre al estar de pie y caminando, cambios en la pelvis, estructura del pie, planta y dedos del mismo. Miembros anteriores más cortos, manos libres, disminución de la mandíbula y dentadura. La característica anatómica diferencial más importante es la extensión de la superficie del cerebro (circunvoluciones) en el hombre $22.260 \mathrm{~cm}^{2}{ }^{2}$, en el gorila sólo $5.300 \mathrm{~cm}^{2}$, que guarda gran correlación con la capacidad intelectual, no así la del volumen que es nula. Se discute entre los

151 Ayala, F. J., La teoría de la evolución, o.c. p. 15.

152 Ayala, F. J., Origen y evolución del hombre, o.c. p. 153.

153 Ayala, F. J., La Teoría de la evolución, o.c. p 15.

154 Ayala, F. J., Origen y evolución del hombre, o.c. pp. 154-158. 
evolucionistas si ocurrió antes el bipedalismo o el aumento del tamaño del cerebro; según Ayala, ambas explicaciones son complementarias, no exclusivas.

\section{Semejanzas y diferencias bioquímicas:}

Las semejanzas bioquímicas entre el hombre y los demás organismos son considerables. La composición química general es muy semejante en todos los seres vivos. Todos poseen DNA, los mismos mecanismos de trascripción y traducción y los mismos codones traducen los mismos aminoácidos, lo que indica con evidencia la unidad de la vida. Esta semejanza aumenta conforme se sube por la escala evolutiva del árbol filogenético y se comparan organismos más cercanos. Esta similitud bioquímica refleja una gran semejanza genética, a juicio del profesor Ayala.

Aunque estas diferencias bioquímicas y genéticas sean mínimas, las anatómicas son mayores, sin embargo, Ayala no cesa de insistir: (...) El hombre aun en cuanto animal, no es uno más: el hombre es único en un sentido peculiar y extremadamente significativo. ${ }^{155}$ Son palabras de G.G. Simpson pero que el autor transcribe y hace propias. Y es que estas semejanzas tan sugestivas y mínimas diferencias biológicas, como manifiesta Ayala, no nos dicen por qué el hombre se percibe a sí mismo como un ser único en el mundo orgánico. En este sentido, es interesante la aportación de Núñez de Castro ${ }^{156}$.

Las diferencias fundamentales entre el hombre y los demás organismos, especialmente los más cercanos a él como los antropoides, radican según Ayala, en el dominio del comportamiento, en modos de vida completamente nuevos y radicalmente diferentes y son: la cultura y el lenguaje, la estructura social y política, la ética y la religión, la literatura, el arte, la tecnología y en general todo lo que constituye la herencia cultural exclusivamente humana.

Evidentemente, la cultura es el atributo distintivo de la humanidad que abarca todas las actividades humanas no estrictamente biológicas, así lo reconoce y afirma Ayala ${ }^{157}$. Para el autor hay dos tipos de herencia en el ser humano: la herencia biológica y la cultural, ambas estrechamente relacionadas. La biológica, como en todos los organismos, se transmite de padres a hijos en las células sexuales portando la información genética contenida en el DNA. La herencia cultural, en cambio, es privativa del ser humano y se transmite por la instrucción y la enseñanza pero también a través del ejemplo y la imitación, los libros, el arte, radio, televisión, etc.

Una forma de cultura es la adaptación al ambiente cambiándolo. Los animales se adaptan al ambiente o mueren. El hombre es capaz de transformarlo adaptando el medio a sus genes. La adaptación cultural prevalece sobre la biológica porque es un proceso más rápido y puede ser dirigido por el propio ser

155 Ayala, F. J., Origen y evolución del hombre, o.c. p. 161.

156 López Azpitarte E. y NúÑEz de Castro, I., Cruzando el puente. Problemas éticos relacionados con la vida. Ed. San Pablo, Madrid. 2011. pp. 232-245.

157 Ayala, F. J., Origen y evolución del hombre, o.c. p. 162. 
humano. La herencia cultural se transmite por el lenguaje, de aquí la íntima y esencial relación entre ambos. La característica peculiar del lenguaje humano es el símbolo. Los animales utilizan un lenguaje de señales acústicas muy reducido con el que sólo manifiestan estados emotivos de agrado o desagrado, nunca ideas y conceptos de los que carecen. El hombre es el único capaz de usar símbolos que no se asemejan a la realidad son, por tanto, convencionales, pero significan algo de mutuo acuerdo social.

En cuanto al origen del lenguaje, apunta Ayala ${ }^{158}$, es un tema de continuo estudio y especulación por lo que se impone antes una aclaración y se evitan confusiones. Es necesario distinguir entre capacidad para el lenguaje y diversidad de lenguajes. Es cierto, dice Ayala, que el origen de la capacidad de lenguaje supone una anatomía normal adecuada para emitir sonidos, pero el origen de esta capacidad no está en los órganos bucales y guturales, sino en ciertas estructuras cerebrales muy relacionadas con el lenguaje. La capacidad del lenguaje corre pareja con el desarrollo del cerebro, el bipedalismo y la destreza manual. La comunicación de ideas hace posible la cultura. Sin embargo, el lenguaje, o mejor, la diversidad de lenguajes o idiomas no depende de la genética biológica y no están determinados por nuestra naturaleza biológica.

Xavier Zubiri, citado por Ayala ${ }^{159}$, hace una incursión filosófica en los sucesos esenciales del proceso evolutivo, incursión de carácter sincretista con la intención, al parecer, de hacer coincidir los criterios de la ciencia con los de la filosofía y teología. En su cita Ayala manifiesta su interés y admiración por la presentación que hace Zubiri del problema de la hominización ${ }^{160}$.

158 AYALA, F. J., Origen y evolución del hombre, o.c. pp. 164-168.

159 Ayala, F. J., «Evolución biológica y evolución cultural», «Arbor», 1968, n 71, p. 23.

160 Zubiri, X., «El origen del hombre», «Revista de Occidente», agosto, 1964, Madrid, pp. 147-173. Es muy aclaradora la lectura de este trabajo filosófico sobre el problema de la hominización, considerado de excelente por el propio Ayala. Para ZuBIRI, X., el problema del origen del hombre ha sido hasta finales del siglo XIX casi exclusivamente teológico pero con la aparición de las diversas disciplinas biológicas se convirtió en problema científico. La evolución humana, siendo un hecho innegable, los mecanismos del proceso, en cambio, son todavía discutibles y discutidos en realidad. Según Zubiri, el hombre pertenece a los antropomorfos, grupo constituido por los póngidos (grandes simios) y los homínidos y éstos, a su vez, formados por los homínidos no humanizados y desaparecidos y los homínidos humanizados o infrahumanos a cuyo philum pertenece el hombre. Lo fundamental, para Zubiri, es tener en cuenta la irreductibilidad de la dimensión intelectual del hombre a todas las dimensiones sensitivas animales. Según esto, Zubiri afirma que es impropio hablar de inteligencia animal; éste se desenvuelve sólo entre estímulos sensitivos conforme a su estado tónico que no entiende; el hombre, en cambio, capta realidades estimulantes. El animal resuelve el problema concreto presente; el hombre es creador y construye para situaciones futuras. Lo fundamental en el proceso evolutivo humano es resolver el problema de la hominización que no es partir de lo prehumano sino de lo infrahumano. Para Zubiri, el austrolopiteco no es animal sino homínido con caracteres humanos rudimentarios, con alguna innovación creadora y, por tanto, con una cierta inteligencia, es verdadero hombre. El hombre es inteligente, no racional. Lo racional es el estado final del desarrollo intelectual. En la evolución humana se va de lo preracional a lo racional. En este sentido, el hombre sólo puede provenir inmediatamente de un homínido y nunca de un equinodermo o de un ave porque el desarrollo de sus 


\section{CONCLUSIÓN}

Desde la perspectiva epistemológica, superadas las dificultades culturales y religiosas que encontró la teoría de la evolución en sus comienzos, el darwinismo, o mejor, el neodarwinismo y teoría sintética o teoría moderna de la evolución, ha encontrado su lugar en el pensamiento filosófico y científico para describir el hecho evolutivo. Gracias a la colaboración mutua entre las distintas disciplinas biológicas y con la singular aportación de la Biología molecular, se han descifrado, en parte, las claves de la mutación biológica, su dependencia del azar y el concepto de selección natural, esencia de la teoría de la evolución, como proceso mecánico y creativo interno de los seres vivos. La selección natural escoge ciegamente aquellas mutaciones genéticas que conducen a un organismo a la mejor adaptación al medio como único y último recurso para la propia supervivencia y mejor reproducción. Son las mutaciones beneficiosas las que son transmitidas a toda la población y sólo a ella, frente al neolamarckismo que ponía el énfasis evolutivo en la influencia del ambiente, hecho desmentido más tarde por los nuevos descubrimientos científicos.

Pese a las profundas lagunas, controversias y deficiencias que todavía presenta la nueva teoría de la evolución biológica y que destacan algunos biólogos, es indudable que constituye un peldaño importante en la reconstrucción del sinuoso y complejo proceso evolutivo de la vida a través de millones de años acudiendo a una razonable explicación causal sin necesidad de recurrir a un creacionismo que no resuelve nada y por naturaleza no es falsable, como afirma el propio Ayala.

Un escollo de gran volumen lo constituye el concepto de especie taxonómica de capital importancia en evolución biológica. Ayala es consciente y sabedor de que las dos teorías esencialista y nominalista quedan en tablas por tener ambas su parte de razón y por tanto, no se puede dar una clasificación natural de los organismos puesto que hay criterios diversos para ello.

La teoría de la evolución tal como la presenta el profesor Ayala resulta correcta aunque incompleta. Correcta porque en nuestros días es la explicación más racional y lógica acerca del origen y amplísima variedad de seres vivos que conocemos y los mecanismos básicos del proceso de cambio. No es ya una simple especulación, sino que muestra pruebas empíricas del hecho evolutivo en el nivel molecular compatibles con la hipótesis puntualista. Es incompleta porque no dispone de los medios necesarios para dar una explicación empírica total de los fenómenos biológicos originales, tales como la formación del DNA

estructuras biológicas no ha llegado al punto que exige una psique intelectiva fundada en la sensibilidad a la que ha trascendido como ocurre en el homínido. En éste, cuando su estructura biológica ha llegado a su nivel adecuado exige la aparición de una psique proporcionada, dada la íntima relación entre estructuras biológicas y psíquicas.

La posición de la teología es distinta porque no ha considerado los estadios previos de la hominización, sino al hombre constituido ya como ser racional y teologal. Lo que no sabemos es el punto crítico evolutivo en el que empieza a ser racional y teologal. 
y código genético, de las proteínas sobre las que debe actuar. Se especula sobre la anterioridad de lo uno o de lo otro; el carácter de la misma vida, la oscuridad sobre la abiogénesis y, sobre todo, de los saltos cualitativos y lagunas en la evolución del ser humano resultan, hoy por hoy, oscuras en muchos puntos, a pesar de las muchas hipótesis que se propongan sobre estas arduas cuestiones. En todo caso, la teoría evolutiva es hoy el único camino viable para hacer ciencia y, en la obra de Francisco J. Ayala, ha encontrado una de sus formulaciones más excelentes.

Doctor en Filosofía

ignacastro@probesi.org

Diego Cano Espinosa

[Artículo aprobado para publicación en diciembre de 2014] 